\title{
EL SENADOR SALVADOR PARGA TORREIRO $(1838-1901)^{*}$
}

\section{THE SENATOR SALVADOR PARGA TORREIRO (1838-1901)}

\author{
FELIPE VALDÉS HANSEN
}

\begin{abstract}
Resumen
Biografía de Salvador Parga Torreiro (18381901), senador, catedrático de Derecho de la Universidad de Santiago y presidente de la Sociedad Económica de Amigos del País de Santiago. A lo largo de su vida desarrolló una importante labor en pro de la modernización socio-económica del país a nivel local, siendo uno de los primeros en reclamar el sufragio femenino en España y Europa en 1870.
\end{abstract}

\section{Palabras clave}

Biografía, Salvador Parga Torreiro, Senado, Universidad y Sociedad Económica Amigos del País de Santiago, sufragio femenino.

\begin{abstract}
Biography of Salvador Parga Torreiro (18381901), a member of the Spanish Senate, a professor at the Law School of the University of Santiago de Compostela, and the president of one of the Spanish societies for economic development. Throughout his life he carried out a fruitful task of promoting local life in the social and economic levels and he became one of the first defenders in Spain and Europe of the right for women's vote.
\end{abstract}

\section{Keywords}

Biography, Salvador Parga Torreiro, Senate, University, Economic Society of Santiago, Women's vote.

* Entregado el 05.05.2008. 
Con Salvador Parga Torreiro acontece lo mismo que con otros muchos políticos que han destacado durante el período de la Restauración, tradicionalmente ignorados, cuando no denostados, desde el punto de vista histórico. La más larga -aunque particular- experiencia democrática de nuestra historia, desde la proclamación de Alfonso XII (1875) hasta el comienzo de la dictadura de Primo de Rivera (1923), es pródiga en casos como el de nuestro biografiado, al cual, como mal menor, podemos incluir en el grupo de los ignorados por los historiadores de Galicia. Su caso es un claro ejemplo de este desinterés tan poco edificante, sobre todo si tenemos en cuenta que él sí se involucró en una efectiva y pragmática modernización de Galicia, al frente de la Sociedad Económica de Amigos del País o la Caja de AhorrosMonte de Piedad de Santiago. Como senador y jurisconsulto su contribución fue más allá de lo local, siendo, por ejemplo, uno de los primeros en defender el sufragio femenino en España y Europa en 1870.

\section{ORIGEN Y FORMACIÓN ACADÉMICA}

Salvador Lope Juan María de las Mercedes Parga Torreiro nació en Santiago el 24 de septiembre de 1838, durante la primera de las guerras carlistas que sacudieron el país a lo largo de aquel siglo. Alumno brillante, comenzó los estudios de bachillerato en 1848, obteniendo a partir del segundo año y hasta que concluyó la carrera universitaria la máxima calificación en todos los cursos y asignaturas. De esta manera ejemplar completó en 1860 la carrera de Derecho en la Universidad de Santiago de Compostela, la cual había iniciado en 1854 siguiendo los pasos de su tutor y tío paterno: José Parga Herce y Chans, profesor y Doctor en Derecho en la misma universidad. Éste, a su vez, continuó el camino iniciado por su padre y abuelo de nuestro biografiado, Andrés Vicente Parga Herce y Mahía (1756-1823), Doctor en Derecho y catedrático en la universidad compostelana, además de alcalde mayor de Santiago ${ }^{1}$.

Su tío paterno, como queda dicho, ejerció de tutor, pues el padre de Salvador, Ramón de Parga y Chans Montenegro (1793-1853), Coronel de Infantería del Ejército y segundo Jefe de Carabineros del Reino, falleció cuando Salvador sólo tenía 15 años de edad ${ }^{2}$. Dos años después también quedó huérfano de madre. Es probable que en la casa familiar Salvador se imbuyese tempranamente del espíritu liberal que tanto le influyó a lo largo de su vida y obra. Además del ambiente y tradi-

1 PARGA PONDAL, Isidro, Genealogía ascendente de Don Salvador Parga y Torreiro 1, Laxe 1980 [manuscrito inédito].

2 Ídem, ibíd. 
ción universitaria, hay que añadir un padre militar comprometido con los principios del liberalismo que defendió de los ataques de franceses, absolutistas y tradicionalistas. Siendo casi un niño Ramón Parga ya se había curtido en unas cuantas batallas durante la guerra de Independencia (Tamames, Medina del Campo, Ciudad Rodrigo, Astorga, etc.), logrando incluso fugarse de los franceses tras haber sido

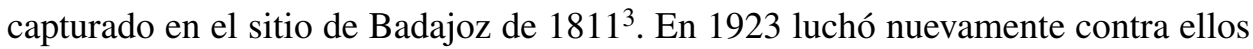
(Los Cien Mil Hijos de San Luis) y los absolutistas españoles hasta replegarse con su batallón en la ciudad de Coruña, segundo bastión del liberalismo en España que fue sitiado por mar y tierra durante más de un $\mathrm{mes}^{4}$. No se salvó de la represión que siguió a la capitulación, pasando varios años de ostracismo militar durante la Década Ominosa de Fernando VII hasta que fue purificado ${ }^{5}$. Después de aquello no faltaron otros hechos de armas relevantes durante la guerra carlista, persiguiendo la partida del cura Merino o hallándose y adhiriéndose al pronunciamiento de Cataluña de $1843^{6}$.

Por parte materna, los Torreiro eran una hacendada e hidalga estirpe con raíces en las tierras del Deza. Establecidos después en la ciudad y alrededores de Coruña (en las casas solariegas de Brexo, San Martiño de Andeiro, Oleiros, etc.), los Torreiro fueron entroncando, sucesivamente, con destacadas familias de la zona. Por lo tanto, por esta rama Salvador era descendiente de la hidalguía rural y de la burguesía urbana coruñesa (mercaderes, etc.), la cual desempeñó puestos de responsabilidad a nivel local (en el concejo, etc.). También los hubo que ocuparon cargos de mucha mayor importancia, como el Caballero de Santiago Pedro Vázquez Torreiro y Lugo, Veedor de la Armada de Flandes y Mar Océano en el siglo XVII ${ }^{7}$.

En 1867 Parga se unió en matrimonio con Carmen Casal Amenedo, hija de un notario de Santiago casado con la descendiente de otra hidalga familia de la provincia. Tuvieron cuatro hijas y un varón, José, que continuando la tradición fue Doctor en Derecho por la Universidad de Santiago. Se puede incluso afirmar que la contribución de nuestro biografiado fue más allá de su vida y obra, pues entre sus descendientes se cuentan algunos destacados personajes de la vida cultural y científica de Galicia. Su hijo José se casó con Matilde Pondal, hija del prestigioso médico Isidro Pondal Abente, perteneciente a una estirpe bien conocida en Galicia y al cual se atribuye buena parte del éxito del balneario de Mondariz durante sus cua-

\footnotetext{
3 Archivo General Militar de Segovia (AGMS), Expedientes personales, Parga Chans, Ramón.

${ }^{4}$ Ibíd.

5 Ibíd.

6 Ibíd.

7 PARGA PONDAL, Isidro, Genealogía ascendente...
} 
renta y dos años como director (1876-1918) ${ }^{8}$. José y Matilde tuvieron nueve hijos, de los cuales sólo sobrevivieron cuatro. Uno de ellos fue el geoquímico Isidro Parga Pondal, cuyo nombre es bien conocido en Galicia por el prestigio internacional de sus investigaciones y su vinculación con el Seminario de Estudos Galegos antes de la Guerra Civil.

En 1859 y 1860 Parga obtuvo los títulos de bachiller y licenciado en Derecho civil y canónico, superando ambos exámenes de grado con la calificación de sobresaliente ${ }^{9}$. En 1865 se doctoró, también con sobresaliente, por la Universidad Central de Madrid, ocupando después la plaza de profesor auxiliar de la Facultad de Derecho de Santiago ${ }^{10}$. El año siguiente se publicó su discurso de investidura como Doctor que dedicó a los derechos de los hijos ilegítimos y fue nombrado catedrático supernumerario de Derecho mercantil y penal. En 1867 ya era catedrático numerario de Derecho político y administrativo, dedicando a esta rama del Derecho el discurso inaugural del curso 1889-90 de las Academias del Derecho de la Universidad de Santiago. Unos meses antes ya había sido nombrado Comendador de Mando de la Real Orden de Isabel la Católica por sus méritos en la enseñanza ${ }^{11}$.

Durante aquellos años consagrados a la enseñanza y el Derecho, además de secretario de la facultad (hasta su renuncia en $1871^{12}$ ), Parga fue socio honorario y presidente (desde 1874) de la Academia Compostelana de Jurisprudencia ${ }^{13}$. Desde 1884 también fue socio correspondiente de la Real Academia de Jurisprudencia y Legislación, de la Real Academia de Gracia y honorario de la Real Academia de Ciencias Morales y Políticas ${ }^{14}$.

\section{EL SUFRAGIO POPULAR: EL DERECHO AL VOTO DE LA MUJER EN 1870}

En junio de 1870, cuando tenía 31 años de edad y a petición del rector, Parga aceptó dar el discurso inaugural del curso académico 1870-71 que dedicó a un tema

\footnotetext{
8 CASTILlO CAMPOS, María Jesús del, Historia del balneario de Mondariz hasta 1936, Universidad Complutense de Madrid, Madrid 1993, 144-6.

9 Archivo Histórico Universitario de Santiago de Compostela (AHUS), Universidad, Expedientes personales, leg. 1.008, $\mathrm{n}^{\circ} .14$.

10 Ibíd.

11 PARGA PONDAL, Isidro, Genealogía ascendente...

12 AHUS, Universidad, Expedientes personales, leg. 1.008, nº 14.

13 PARGA PONDAL, Isidro, Genealogía ascendente...

14 Ídem, ibíd.
} 


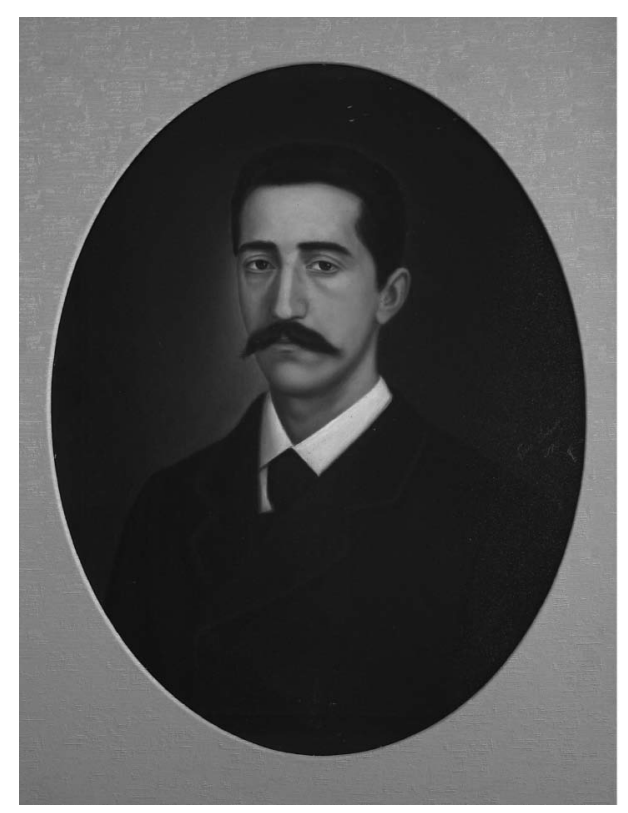

Figura 1: Salvador Parga Torreiro por J. Salgado.

de absoluta actualidad entonces: el sufragio popular o universal ${ }^{15}$. Dos años antes el pronunciamiento de los generales Prim, Serrano y Topete había puesto fin al reinado de Isabel II e iniciado el Sexenio Revolucionario o Democrático. Después de aprobarse la nueva Constitución de 1869, se promulgó el decreto sobre el sufragio universal para todos los españoles -varones- mayores de 25 años, inscritos en el padrón de vecindad, sin distinción de fortuna o cultura. En este contexto redacta y lee su discurso Parga que, ya entonces, demuestra el compromiso con la regeneración de la sociedad y la economía que marcará su trayectoria vital, ya fuese a través del Derecho, la Sociedad Económica de Amigos del País, la Caja de AhorrosMonte de Piedad o el Senado.

En su discurso Parga impugna las exclusiones al sufragio que, según él, se denomina pomposamente como universal, a pesar de impedir el voto a clases enteras. A través de las impugnaciones defiende el derecho al voto de los detenidos en espera de juicio, de los deudores de fondos públicos, de los pobres, de los analfabetos y de las mujeres. Así sólo quedarían privados del voto los menores de edad, los presos y los deficientes mentales. Siguiendo a otros especialistas del Derecho

15 AHUS, Universidad, Expedientes personales, leg. 1.008, $\mathrm{n}^{\circ} .14$. 
político (Stuart Mill, Thomas Hare, etc.), también se ocupa de las posibles alternativas para asegurar la representación política de las minorías, así como del creciente temor a que la extensión del sufragio conllevase la elección de gobiernos ineficaces. Al respecto sopesa la posibilidad de establecer alguno de los mecanismos que se barajaban entonces, como la desigualdad en el valor del voto en función de la inteligencia, formación u otras aptitudes, pero nunca de la riqueza. Si en el caso de otras exclusiones disiente con Stuart Mill, que niega el voto a los pobres o a quienes dependan económicamente de los demás, coincide plenamente con él en lo que atañe a la mujer. De entre todas las impugnaciones es la que merece un comentario más pormenorizado, por lo temprano de la fecha. Consideraciones que hoy nos parecen obvias no lo eran, ni mucho menos, en la España de 1870. Su impugnación de la exclusión del sufragio femenino es, ante todo, una pionera e insólita defensa de los derechos de la mujer a la que no duda en considerar igual al hombre:

\begin{abstract}
"O son falsas las razones que en apoyo de la extensión del sufragio alegan sus sostenedores, o no es posible negarlo al sexo femenino. La justicia electoral, las ventajas de la forma democrática, que se invocan respecto al hombre, tienen aplicación cumplida a la mujer: ella es igual al hombre en el recto sentido de la palabra igualdad: ella es susceptible de perfeccionamiento, como el hombre puede serlo. ¿Por qué, pues, no se ha de atender a su igualdad y a su perfectibilidad?"16.
\end{abstract}

Parga no sólo considera enriquecedor la intervención de la mujer en la política, sino también como algo absolutamente necesario, pues "siendo físicamente más débiles, dependen más de la ley y la sociedad para su protección”. Es interesante comparar este discurso con el de investidura de Doctor, cinco años antes, en el que al ocuparse de los derechos de los hijos ilegítimos evidencia algún prejuicio muy extendido socialmente entonces, como la argucia de la mujer para contraer matrimonio a través del embarazo premeditado ${ }^{17}$. En este sentido, cabe preguntarse si

16 PARGA TORREIRO, Salvador, Discurso leído en la Universidad de Santiago en solemne inauguración del curso académico de 1870 a 1871, por el doctor D. Salvador Parga Torreiro, Santiago 1870, 31-2.

17 ÍD., Discurso leído ante el Claustro de la Universidad Central en el solemne acto de recibir la investidura de Doctor en la facultad de Derecho, Sección de Derecho Civil y Económico, por Salvador Parga Torreiro, Madrid 1866, 16. 
su posterior matrimonio con Carmen Casal Amenedo (1867) pudo influir en este cambio y defensa de los derechos de la mujer, como fue el caso del citado Stuart Mill con Harriet Taylor, al cual alude repetidamente a lo largo de su discurso publicado un año después que la obra de S. Mill El sometimiento de las mujeres (1869). Además, su posicionamiento al respecto difiere con el criterio de las sociedades económicas de amigos del país sobre la enseñanza de la mujer, la cual se orientaba al buen desempeño de las tareas domésticas o una mejor capacitación, con el único fin de aumentar su remuneración ${ }^{18}$. Algo con lo que, a nivel particular, disiente Parga:

"Si se quiere decir que sólo las labores del hogar doméstico le son peculiares, creemos se puede contestar que, ni la ley es la llamada a señalar al individuo los trabajos en que haya de ocuparse, ni tampoco es exacto que la mujer haya nacido exclusivamente para regir el interior de su casa, para hilar y coser las ropas de la familia" 19 .

Curiosamente, su sucesor en el Senado como representante de las sociedades económicas del noroeste fue Rafael María de Labra Cadrana, conocido republicano abolicionista y defensor también de los derechos de la mujer. Por su interés e importancia incluimos el discurso de Parga sobre el sufragio en el apéndice de este artículo. Muchos años después de su lectura ante el claustro universitario, La Ilustración Española y Americana (1884) destacará elogiosamente aquel discurso al referirse a los méritos de Parga, con motivo de los actos del centenario de la Económica de Santiago:

"La oración inaugural que leyó en la apertura del curso de 1870 a 1871 es un trabajo notabilísimo, en el cual se dilucidaban las más trascendentes cuestiones acerca del sufragio popular, mucho antes de que las Cámaras españolas se preocupasen con las reformas propuestas por Tomás Hare y otros publicistas, habiendo merecido que un profesor ilustre de Italia la calificase con los más lisonjeros términos y que la citara con gran elogio una egregia escritora que es honra de las letras patrias" 20 .

18 FERNÁNDEZ CASANOVA, Carmen, La Sociedad Económica de Amigos del País de Santiago en el siglo XIX, Sada 1981, 85-6.

19 PARGA TORREIRO, Salvador, El sufragio popular..., 35.

${ }^{20}$ La Ilustración Española y Americana, 22-8-1884, 99. 


\section{PRESIDENTE DE LA SOCIEDAD ECONÓMICA DE AMIGOS DEL PAÍS DE SANTIAGO (1877-1884) Y DIRECTOR DE LA CAJA DE AHORROS- MONTE DE PIEDAD (1886-1901)}

Desde 1877 y hasta 1884 Parga fue el presidente de la Sociedad Económica de Amigos del País de Santiago, fundada en 1784, como tantas otras en el resto de España, para combatir el atraso económico e industrial a nivel local o provincial. Según la prensa, a él se debía el próspero estado de la Económica, siendo el impulsor de la mayor parte de las escuelas que sostenía esta sociedad, las cuales estaban dirigidas, principalmente, a las clases más desfavorecidas ${ }^{21}$. Durante su dirección se crea la Escuela de Música y Modelado (1877), la de Comercio (1878-79), la de Labores (1880), la de Artes y Oficios (1880) y se reabre ese mismo año la Escuela de Adultos (cerrada desde 1865). En 1881 también se funda la de idiomas (inglés y alemán), mientras que en 1882 se implantan numerosas cajas de ahorros escolares, destinadas a favorecer el ahorro de los estudiantes y mejorar su situación ${ }^{22}$.

Durante estos años la Económica publicó el mayor número de informes sobre los problemas que aquejaban al sector primario, prestando especial atención al pesquero. El desarrollo de la red de ferrocarriles fue también objeto de atención preferente, en consonancia con el interés por las infraestructuras que caracterizó la labor de Parga como senador. Y antes de convertirse en el presidente de la Económica, Parga realizó, conjuntamente con otros colegas de la Económica, el informe sobre foros, subforos y otras cargas semejantes que se conocen en el antiguo reino de Galicia (1875). En el mismo planteaban la necesaria reforma de la institución foral, pero no su abolición atendiendo a la particular realidad del campo gallego ${ }^{23}$.

Su primer año al frente de la Económica coincidió con la visita del rey Alfonso XII, el cual presidió una de las sesiones de 1877, mientras que su último año al frente de la misma (1884) coincidió con los festejos -que presidió- del centenario de su fundación. La Ilustración Española y Americana se hizo eco de los mismos, incluyendo unos grabados que adjuntamos ${ }^{24}$. Además de la santiaguesa, fue socio correspondiente de la Sociedad Económica de la Habana (desde 1881) y honorario de la sevillana (desde 1884).

21 Ibíd., 99; El Eco de Santiago, 29-4-1901.

22 FERNÁNDEZ CASANOVA, Carmen, "Real Sociedad Económica de Amigos del País de Santiago", Gran Enciclopedia Gallega 26, Santiago 1974, 104; Ídem, La Sociedad Económica..., 83-100.

23 PORTABALES VÁZQUEZ, Ángel, "Parga Torreiro, Salvador", GEG 24, Santiago 1974, 40. FERNÁNDEZ CASANOVA, Carmen, "Real Sociedad...", 115-24.

${ }^{24}$ La Ilustración Española..., 22-8-1884, 98-100. 


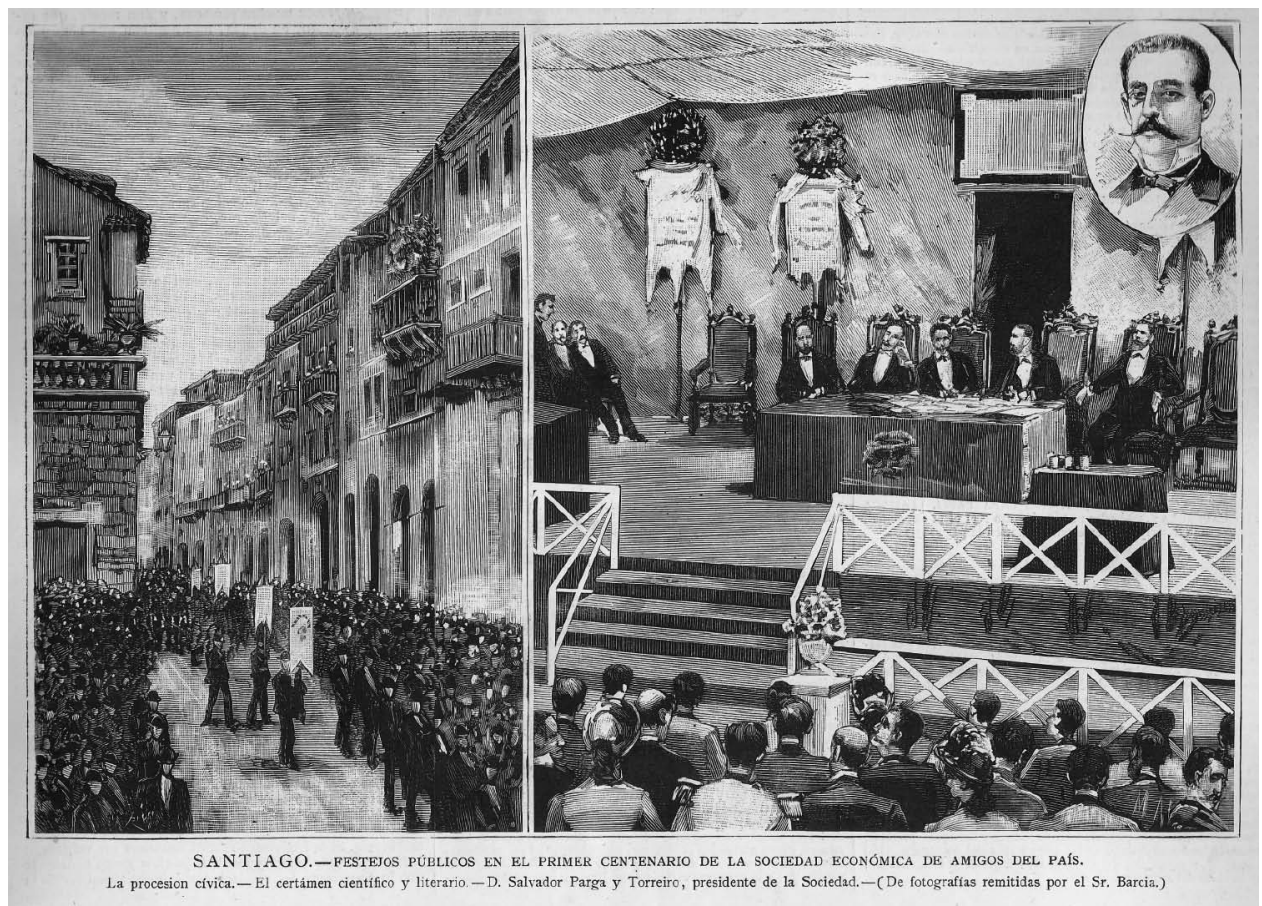

Figura 2: Festejos del centenario de la Sociedad Económica de Amigos del País de Santiago, presididos por Salvador Parga Torreiro. Xilografía de La Ilustración Española y Americana (1884).

Estando al frente de la Económica se fundó en Santiago la Caja de AhorrosMonte de Piedad (1880), de la cual fue su director desde $1886^{25}$. Si bien se trató de un proyecto conjunto de los socios de la Económica planteado desde tiempo atrás, lo cierto es que no llegó a ser una realidad hasta que Parga impulsó decididamente el proyecto, como subraya la prensa de la época o la bibliografía más reciente:

"En definitiva, era el catedrático de Derecho Político y Administrativo de la Universidad, Salvador Parga Torreiro, quien estaba al frente de la Sociedad Económica por aquellos años. Fue él, en definitiva, quien dirigió la puesta en marcha de la Caja de Ahorros y Monte de Piedad compostelana. En este caso la persona fue capital en el origen de la entidad económica en cuestión"26.

25 El Eco de Galicia, 29-4-1901.

26 GARCÍA IGLESIAS, José Manuel, "Historia y arte en La Casa Grande del Pozo", Historia e Arte na Casa Grande do Pozo. Santiago de Compostela. Fundación Caixa Galicia, Santiago de Compostela 2002, 25, 181. 


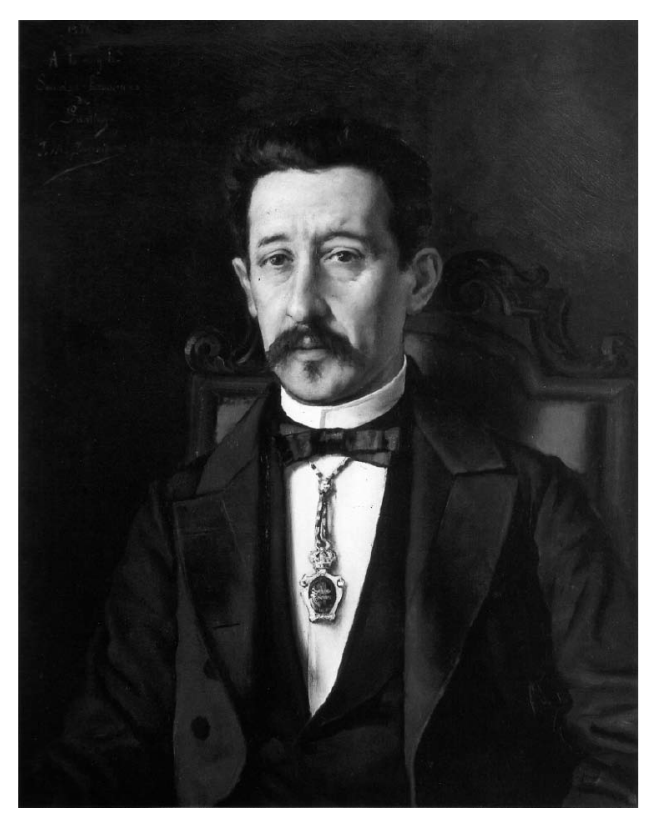

Figura 3: Salvador Parga Torreiro por J.M. Fenollera en 1887.

En su primer año al frente de la Económica se redactaron los estatutos de la que sería la segunda Caja de Ahorros-Monte de Piedad de Galicia, tras la de Coruña (1842). Los estatutos fueron aprobados en 1878 y al año siguiente se hace lo propio con el reglamento, al tiempo que se ocupa un local -cedido por el ayuntamiento- en el convento de San Agustín. En 1880 comenzaron exitosamente las operaciones financieras que, en pocos años, hicieron necesario el traslado de las oficinas a un local más amplio y adecuado. Fue ésta otra iniciativa personal de Parga, cuyas gestiones hicieron posible la construcción del actual edificio en la plaza compostelana que hoy lleva su nombre ${ }^{27}$.

De enorme importancia cabe considerar la creación de esta nueva entidad bancaria, pues el Monte de Piedad funcionó como una casa de préstamos a muy bajo interés para los jornaleros y artesanos que, de este modo, pudieron escapar de los abusivos préstamos por parte de los particulares. Cien años después, en 1980, la Caja de Ahorros de Santiago se integró en Caixa Galicia, la cual surgió dos años antes a raíz de la fusión de las otras históricas cajas de ahorros de Galicia (las de

27 PARGA TORREIRO, Salvador, Memoria leída en el acto de la inauguración solemne del edificio propio de la Caja de Ahorros-Monte de Piedad de Santiago...,1897. FERNÁNDEZ CASANOVA, Carmen, La Sociedad Económica..., 185-98. 
Coruña, Lugo y Ferrol). Además de su dirección al frente de esta entidad bancaria, Parga también fue consejero del otro gran banco de la ciudad, la sucursal del Banco de España, establecida en buena medida (1886) por el interés de la Sociedad Económica de Amigos del País ${ }^{28}$.

\section{SENADOR DEL REINO (1892-1901)}

Tras no obtener el escaño senatorial como representante de la Universidad de Santiago en 1877, Parga fue elegido en 1892 por las sociedades económicas del noroeste o del distrito de León ${ }^{29}$. Por lo tanto, actuó como representante en Madrid de las sociedades económicas de Santander, Asturias, León, Zamora, Ribadeo y Santiago, de la que fue su director y por entonces socio honorario. Si en la primera elección encontró cierta oposición, en las restantes obtuvo el escaño con la totalidad de los votos de los compromisarios de las sociedades. Fue reelegido en todas las elecciones hasta su fallecimiento, siendo sustituido, como ya se dijo, por el citado republicano Rafael María de Labra ${ }^{30}$.

No obstante, Parga se consideraba como un hijo de la Universidad de Santiago, por lo que no es de extrañar que en 1899 intentase nueva e infructuosamente alcanzar el Senado como representante de la misma. Esta vez fue derrotado por el jurisconsulto e historiador del Derecho español Eduardo de Hinojosa. Ello demuestra que, a pesar de todo, contaba con un mayor apoyo extramuros del claustro universitario, tras haber establecido una red de poder local por méritos propios y a la sombra de su mentor político Montero Ríos (en el ayuntamiento, donde fue concejal; en el colegio de abogados, del cual fue vicedecano; en la cámara de comercio, cuyos intereses defendió; en la Económica que presidió, etc.). Dentro de lo que se ha dado en denominar monterismo estaba muy bien posicionado y conceptuado, tal como reconoció uno de sus compañeros de facción, el director de la Gaceta de Galicia Bibiano Fernández:

"Buen consejero, buen amigo, consecuente político, figuraba entre los principales elementos del comité monterista, siendo uno de los predilectos de su ilustre jefe" 31 .

28 FERNÁNDEZ CASANOVA, Carmen, La Sociedad Económica..., 185-6.

29 CORES TRASMONTE, Baldomero, Os senadores da Universidade de Santiago, Cuadernos de Estudios Gallegos, Anexo 26; Santiago de Compostela 1998, 69, 71.

30 Ibíd.

${ }^{31}$ La Gaceta de Galicia, 30-4-1901. 
Su carrera parlamentaria se caracterizó por una intensa participación en las primeras legislaturas que decayó notablemente al final, apagada la ilusión inicial o agravado el problema de salud que le acompañó buena parte de su vida y del que ya tenemos vaga noticia en 1871, cuando renunció a la secretaría de la Facultad de Derecho de Santiago. A la primera etapa corresponden todos los discursos pronunciados en el Senado, los cuales abordaban asuntos de interés general o específicamente gallegos. Entre los asuntos generales se ocupó de la prescripción de los bienes de dominio público, la reforma del régimen aduanero y las tarifas de ferrocarriles o la defensa de la carrera consular frente a la diplomática en los presupuestos generales $^{32}$. Por lo que respecta a los problemas gallegos presentó una enmienda a los presupuestos generales del Estado de 1892-93, tratando de evitar lo inevitable: la supresión de la Audiencia criminal de Santiago, pues éstos sólo contemplaban una audiencia por provincia y en la capital correspondiente (en este caso Coruña). Esto último le suscitaría una especial preocupación, como influyente santiagués y catedrático de Derecho convencido del error de suprimir esta audiencia, a pesar de la escasez de juicios, teniendo en cuenta su ubicación en una ciudad universitaria que, además, es el centro geográfico de la provincia ${ }^{33}$.

Su último discurso, en la legislatura siguiente, lo dedicó al problema de las exportaciones de ganado vacuno gallego a Inglaterra, paralizadas preventivamente por las autoridades de aquel país alegando infundados motivos sanitarios, según la Escuela de Veterinaria de Santiago ${ }^{34}$. Respondía así a la preocupación que sobre el asunto se le transmitió desde la Cámara de Comercio de Santiago, presionando al gobierno para que actuara en consecuencia en el orden económico con Inglaterra. Una vez más, a través de esta intervención, Parga demostró su conocimiento de los problemas que aquejaban al rural, familiarizado como estaba con este mundo que gravitaba en torno a la pequeña ciudad del Apóstol. Además, conocía con profundidad el problema ganadero que la Sociedad Económica ya había abordado unos años antes (Informe sobre las causas de la crisis que atraviesa el ganado vacuno en Galicia y los medios de remediarla, 1887).

Entre los senadores las intervenciones de Parga se caracterizaron siempre por "la serenidad, mesura y profundidad" propias de su persona ${ }^{35}$. Formó parte de un total de treinta y siete comisiones, en su mayor parte para la aprobación de carrete-

32 Diario de las Sesiones de Cortes. Senado, 20-4-1892, 2757; 21-4-1892, 2761-71; 10-5-1892, 3090-5; 11-5-1892, 3101-8; 23-6-1892, 3823-8.

33 Ibíd., 20-6-1892, 3722-5.

34 Ibíd., 6-7-1894, 2633.

${ }^{35}$ CORES TRASMONTE, Baldomero, Os senadores..., 75. 
ras y vías de ferrocarril en el noroeste de España ${ }^{36}$, en sintonía con la preocupación de las sociedades económicas por el desarrollo de las infraestructuras. Participó en otras comisiones sobre diversos asuntos, incluyendo la de Honor y Mensaje encargada de transmitir la felicitación del Senado al rey por su onomástica en 1894. Como no podía ser de otra manera, también formó parte de la comisión encargada de sacar adelante el proyecto de Montero Ríos para declarar monumento nacional la catedral de Santiago, en la legislatura de 1896-98. Asimismo, formó parte de la comisión que, paralelamente, hizo lo propio con el convento e iglesia de San Francisco de Pontevedra, el otro feudo político de Montero Ríos. De esta manera, se dio un paso importante de cara a la conservación de ambos monumentos, garantizando las partidas presupuestarias del Estado.

Sus clases, las reuniones de la Económica, los viajes a Madrid para asistir a las sesiones del Senado y la dirección de la Caja de Ahorros-Monte de Piedad ocuparon el quehacer diario de Parga en los últimos años de su vida. Nuestro biografiado falleció a la edad de 62 años, en la mañana del 28 de abril de 1901. Según la prensa local, que dedicó extensas necrológicas al finado, su muerte fue muy sentida en la ciudad por la que tanto hizo, siendo el entierro una gran manifestación de duelo público. Al funeral y entierro, en el cementerio de la Cofradía del Rosario, asistieron todos los representantes de los poderes e instituciones locales (Ayuntamiento y Universidad de Santiago, Sociedad Económica, Colegio de Abogados, Cámara de Comercio, Círculo Mercantil, Caja de Ahorros-Monte de Piedad, Escuela de Veterinaria, de Artes e Industrias, etc.). Las clases se interrumpieron aquel día y varios de sus alumnos fueron los encargados de conducir el féretro ${ }^{37}$. En la comitiva participaron gentes de todas las clases sociales compostelanas, incluyendo las menos favorecidas que reconocían así su labor. En los días siguientes algunos de sus discípulos más notables enviaron a la prensa local sentidas notas de duelo, mientras que algunas sociedades y el ayuntamiento hicieron constar su pesar en las actas por la muerte de Salvador Parga Torreiro ${ }^{38}$. La plaza del casco viejo de Santiago que hoy lleva su nombre fue una acertada propuesta de la Sociedad Económica de Amigos del País, poco después de su fallecimiento ${ }^{39}$. Se trata de un lugar doblemente idóneo y honroso para dignificar su memoria, pues allí tiene hoy su sede dicha sociedad (desde 1955), en el mismo edificio que por aquel entonces, y a instancia suya, ocupó la Caja de Ahorros-Monte de Piedad de la que fue fundador y director.

\footnotetext{
36 Página de internet del Senado de España.

37 El Eco de Santiago, 29-4-1901; La Gaceta de Galicia, 30-4-1901.

38 El Eco de Santiago, 6-5-1901; La Gaceta de Galicia, 2-5-1901, 5-5-1901.

39 La Gaceta de Galicia, 2-5-1901.
} 


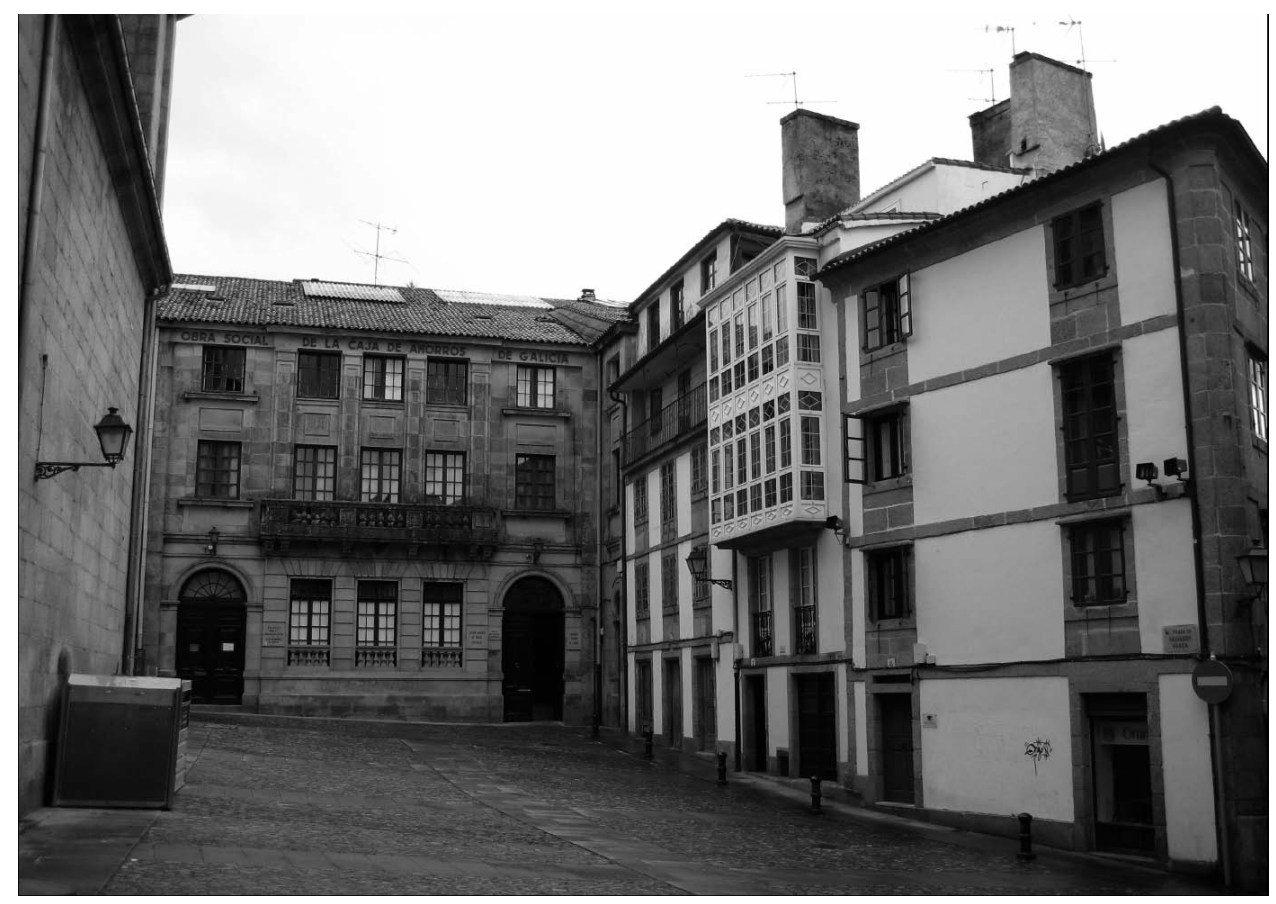

Figura 4: Plaza de Salvador Parga en Santiago de Compostela (Foto F. Valdés Hansen)

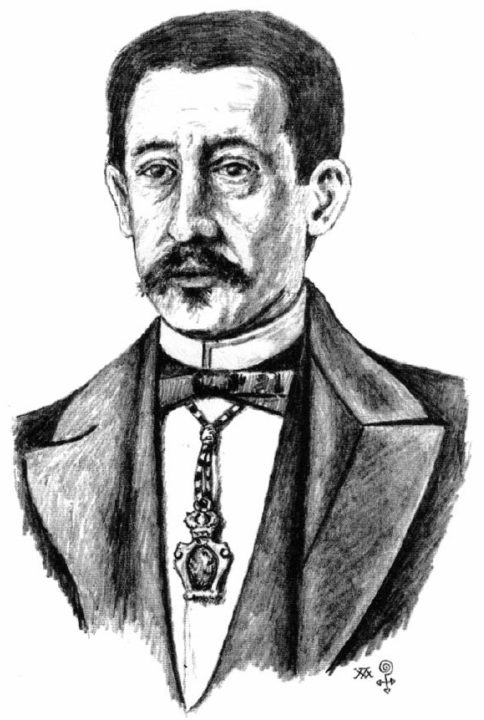

Figura 5: Salvador Parga Torreiro por X.A. García González-Ledo. 
ASCENDENCIA PARGA DE SALVADOR PARGA TORREIRO

\author{
ANDRÉS LOPEZ DE SEIXAS Y PARGA \\ JACINTA DE SOTO QUEIZÁN \\ † 1710 (Santiago) \\ I \\ Ma MAGDALENA LÓPEZ DE SEIXAS Y PARGA \\ 1678 (Lugo) / † 1717 (Santiago) \\ SILVESTRE FRANCISCO NOVO Y HERCE \\ $\dagger 1705$ (Santiago) \\ Señor de la Casa de Beizana (Zas, Vimianzo). \\ I \\ JOSEPH ANTONIO DE PARGA HERCE Y NOVO \\ 1703 (Santiago) \\ Procurador y alcalde ordinario de Santiago. \\ MARÍA IGNACIA MAHÍA Y ROCA \\ I \\ ANDRÉS VICENTE PARGA HERCE Y MAHÍA \\ 1756 (Santiago) / † 1823 (Santiago) \\ Catedrático y Alcalde mayor de Santiago. \\ CC \\ JUANA CHANS MONTENEGRO Y DE SILVA \\ $\dagger 1835$ (Santiago) \\ 1 \\ RAMÓN DE PARGA Y CHANS MONTENEGRO \\ 1793 (Santiago) / 1853 (Santiago) \\ Coronel de Infantería del Ejército y $2^{\circ}$ Jefe de Carabineros del Reino. \\ Caballero, cruz y placa de San Hermenegildo. \\ Cruces de San Fernando y de Guerra de Distinción. \\ CC \\ RITA TORREIRO Y VARELA \\ 1808 (Brexo, Cambre) / † 1855 (Santiago) \\ I \\ SALVADOR PARGA TORREIRO \\ 1838 (Santiago) / † 1901 (Santiago)
}




\title{
ASCENDENCIA TORREIRO DE SALVADOR PARGA TORREIRO
}

\author{
ALDONZA TORREIRO \\ Casa de Freufe (S. Pedro de Merlín, Agolada) \\ CC \\ SANCHO VÁZQUEZ VARELA \\ Casa do Salto (S. Mamede da Goela, Antas de Ulla) \\ I \\ JUAN VÁZQUEZ TORREIRO \\ Casa de Freufe \\ $\mathrm{CC}$ \\ MARÍA DE LOOÑO \\ Casa de Looño (Vila de Cruces) \\ I \\ PEDRO VÁZQUEZ TORREIRO Y LOOÑO \\ 1590 (Freufe) $/ †$ (Coruña) \\ Señor de las casas de Freufe y Candame. \\ CC \\ INÉS PÉREZ DE LUGO Y SOMORROSTRO \\ 1588 (Coruña) $/ \dagger$ (Coruña) \\ I \\ PEDRO VÁZQUEZ TORREIRO Y LUGO \\ 1621 (Candame, Arteixo) / † 1679 \\ Caballero de Santiago. Veedor general de la Armada de \\ Flandes y Mar Océano, y del Ejército de Cataluña. \\ Fundador del vínculo y mayorazgo familiar. \\ CC \\ CATALINA DE SOTOMAYOR Y LAMAS

$$
+1673 \text { (Coruña) }
$$ \\ I \\ IGNACIO VÁZQUEZ TORREIRO Y SOTOMAYOR \\ 1665 (Coruña) / † (Andeiro) \\ Capitán y Sargento mayor del Tercio de Galicia.$$
\text { CC }
$$ \\ Ma ANTONIA PARDO MONTENEGRO Y SÁNCHEZ DE PRADO \\ † 1702 (Coruña) \\ I \\ ANTONIO TORREIRO SOTOMAYOR Y MONTENEGRO \\ 1686 (Coruña) \\ Regidor perpetuo de Coruña.$$
\text { CC }
$$ \\ JACINTA CAAMAÑO SOTOMAYOR Y BERMÚDEZ DE VILLAMISAR \\ 1720 (Andeiro) $/+$ (Andeiro) \\ I \\ PEDRO IGNACIO TORREIRO CAAMAÑO \\ 1743 (S. Martiño de Andeiro, Cambre) \\ Regidor perpetuo y cap. de milicias de Coruña. \\ Poseedor del vínculo y mayorazgo. \\ Ma JOSEFA VEREA \\ CC \\ $\dagger 1783$ (Brexo, Cambre) \\ I \\ RAMÓN PELAYO TORREIRO VEREA \\ 1778 (Brexo, Cambre) \\ Bachiller en Leyes. \\ CC \\ JOSEFA VARELA-CAAMAÑO Y VARELA \\ 1789 (Oleiros) $/+1828$ (Coruña) \\ (Hidalgos con información de nobleza en Coruña) \\ I \\ RITA TORREIRO Y VARELA \\ 1808 (Brexo, Cambre) $/ \uparrow 1855$ (Santiago) \\ CC \\ RAMÓN DE PARGA Y CHANS MONTENEGRO \\ 1793 (Santiago) / † 1853 (Santiago) \\ Coronel de Infantería del Ejército. \\ I \\ SALVADOR PARGA TORREIRO \\ 1838 (Santiago) $/ \dagger 1901$ (Santiago)
}


Expediente de bachillerato

\begin{tabular}{lll}
\hline CURSO & ASIGNATURA & CALIFICACIÓN \\
\hline $1848-49$ & $1^{\circ}$. de Filosofía & Bueno \\
\hline $1849-50$ & $2^{\circ}$. de Filosofía & Sobresaliente \\
\hline $1850-51$ & $3^{\circ}$. de Filosofía & Sobresaliente \\
\hline $1851-52$ & $4^{\circ}$. de Filosofía & Sobresaliente \\
\hline $1852-53$ & $5^{\circ}$. de Filosofía & Sobresaliente \\
\hline $1853-54$ & $6^{\circ}$. de Filosofía & Sobresaliente \\
\hline
\end{tabular}

AHUS, Fondo Universidad, Expedientes académicos, leg. 1.008, exp. 14.

Expediente universitario

\begin{tabular}{lll}
\hline CURSO & ASIGNATURA & CALIFICACIÓN \\
\hline $1854-55$ & $1^{\circ}$. de Jurisprudencia & Sobresaliente \\
\hline $1855-56$ & $2^{\circ}$. de Jurisprudencia & Sobresaliente \\
\hline $1856-57$ & $3^{\text {o }}$ de Jurisprudencia & Sobresaliente \\
\hline $1857-58$ & $4^{\circ}$. de Jurisprudencia (Derecho) & Sobresaliente \\
\hline $1857-58$ & $4^{\circ}$. de Jurisprudencia (Filosofía) & Sobresaliente \\
\hline $1858-59$ & Derecho canónico & Sobresaliente \\
\hline $1858-59$ & Derecho político y administrativo & Sobresaliente \\
\hline $1858-59$ & Procedimientos judiciales & Sobresaliente \\
\hline $1858-59$ & Práctica con abogado $\left(1^{\circ}\right)$. & Asistió \\
\hline $1859-60$ & Disciplina general eclesiástica & Sobresaliente \\
\hline $1859-60$ & Práctica forense & Sobresaliente \\
\hline $1859-60$ & Práctica con abogado $\left(2^{\circ}\right)$. & Asistió \\
\hline
\end{tabular}

Premios en el $2^{\circ}, 3^{\circ}$ y $4^{\circ}$ año de Jurisprudencia, y en las asignaturas de Disciplina y Práctica forense del curso 1859-60. AHUS, Fondo Universidad, Expedientes académicos, leg. 1.008, exp. 14. 


\section{Trayectoria de Salvador Parga Torreiro}

\begin{tabular}{ll}
\hline AÑO & CARGO \\
\hline 1838 & Nace en Santiago (24 septiembre). \\
\hline 1853 & Fallecimiento del padre. \\
\hline 1854 & Bachiller en Filosofía. Inicia la carrera en Derecho. \\
\hline 1855 & Fallecimiento de la madre. \\
\hline 1860 & Licenciado en Derecho por la USC. \\
\hline 1865 & Doctor en Derecho por la Universidad Central. \\
\hline 1866 & Catedrático supernumerario de la USC. \\
\hline 1877 & Catedrático numerario de la USC. Contrae matrimonio. \\
\hline 1886 & $\begin{array}{l}\text { Presidente de la Academia compostelana de Jurisprudencia. } \\
\text { Santiago (hasta 1884). }\end{array}$ \\
\hline 1889 & $\begin{array}{l}\text { Director de la Caja de Ahorros-Monte de Piedad de Santiago } \\
\text { (hasta 1901) }\end{array}$ \\
\hline 1892 & $\begin{array}{l}\text { Comendador de Mando de la Real Orden de Isabel la } \\
\text { Católica, por méritos en la enseñanza. }\end{array}$ \\
\hline 1901 & $\begin{array}{l}\text { Senador del Reino en representación de las sociedades } \\
\text { económicas del noroeste (hasta 1901). }\end{array}$ \\
\hline
\end{tabular}

\section{Publicaciones de Salvador Parga Torreiro}

Informe de la Sociedad Económica de Amigos del País de Santiago elevado al Excmo. Sr. Ministro de Gracia y Justicia, en virtud de orden del mismo de 27 de marzo de 1874, sobre foros, subforos y otras cargas semejantes que se conocen en el antiguo reino de Galicia, Imprenta de J.M. Paredes, Santiago 1875 (publicación conjunta con M. Salvá, J. Viñas, J. Gil, M. Martínez, A. Junquera, J. Rodríguez, G. Neyra y P. Zamora). 
Los derechos del hijo reconocido por el padre o la madre, o por los dos de común acuerdo. Discurso leído ante el claustro de la Universidad Central en el solemne acto de recibir la investidura de Doctor en la Facultad de Derecho, sección de Derecho Civil y Económico, por D. Salvador Parga Torreiro, Imprenta de El Heraldo, Madrid 1866.

El sufragio popular. Discurso leído en la Universidad de Santiago en la Solemne inauguración del curso Académico de 1870 a 1871, por el Doctor D. Salvador Parga Torreiro, Catedrático de Elementos del Derecho político y administrativo español, Establecimiento tipográfico de J.M. Paredes, Santiago 1870.

Extensión del Derecho político. Discurso leído en la Inauguración de las Academias de Derecho de la Universidad de Santiago por el Ilmo. Sr. Dr. D. Salvador Parga Torreiro, catedrático de Derecho político y administrativo, el día 3 de noviembre de 1889, Imprenta de J. M. Paredes, Santiago 1889.

Memoria leída en el acto de la inauguración solemne del edificio propio de la Caja de Ahorros-Monte de Piedad de Santiago, en 19 de Julio del Año Santo de 1897, por el Director del benéfico establecimiento D. Salvador Parga y Torreiro, Imprenta de J.M. Paredes, Santiago 1897.

\section{APÉNDICE}

El sufragio popular. Discurso leído en la Universidad de Santiago, en la solemne inauguración del curso académico de 1870 a 1871, por el Doctor D. Salvador Parga Torreiro, Catedrático de Elementos del Derecho político y administrativo español, Imprenta de J.M. Paredes, Santiago 1870, 58 páginas.

[1] Introducción. [2] Sobre la extensión del sufragio. [3] Derecho al sufragio de los presos en espera de juicio. [4] Derecho al sufragio de los deudores públicos. [5] Derecho al sufragio de los pobres. [6] Derecho al sufragio de los analfabetos. [7] Derecho al sufragio de las mujeres. [8] Sobre la eficacia del sufragio: las minorías. [9] Sobre el grado en que ha de poseerse.

Excmo. e Ilmo. Sr.

[1] Los que llevamos sobre el pecho, como honroso lema de la profesión a que vivimos consagrados, la inscripción: Perfundet omnia luce que se lee en nuestras medallas, 
natural es que en las solemnidades académicas, como siempre, dediquemos la parte principal a la difusión de la ciencia. Misión augusta, misión grata, para los que nos sacrificamos constantemente a la verdad; pero difícil y con especialidad en circunstancias como las presentes, en que el merecido concepto de esta Escuela, y las profundas y elocuentes lecciones que desde esta tribuna han dado tantos y tan esclarecidos profesores, hacen concebir grandes y justísimas esperanzas. Me inquieta la idea de que por esta vez no habrán de quedar debidamente satisfechas las vuestras, no por defecto de intención, pero sí por falta de fuerzas del que tiene el alto honor de dirigiros la palabra; me anima, no obstante, en el desempeño del deber que hoy vengo a cumplir, por designación de mi distinguido Gefe (sic), una consideración muy halagüeña. Elevo mi voz en el venerado recinto de la Universidad de que soy hijo, en el suelo compostelano que me recibió al nacer; y el respetuoso y acendrado amor que hacia vos, insigne Claustro, siento, y el entusiasta y constante cariño con que vos, ilustre pueblo de Santiago, hacéis latir mi corazón, me mueven a esperar, y creo habré de conseguirlo, con vuestro amor y con vuestro cariño, generosa benevolencia, un juicio indulgente.

En la elección de materia no he tenido que vacilar. Aun cuando la circunstancia de tener a mi cargo la enseñanza de la asignatura de Elementos del Derecho político y administrativo español, no me inspirara singular predilección hacia la misma, el estado en que se encuentra como una de las ramas de la ciencia jurídica y su importancia particular en los actuales tiempos, serían motivos suficientes para que en los puntos que ella abraza fijase preferentemente mi atención.

No es posible desconocer que el Derecho político forma hoy una de las interesantes secciones de la ciencia del Derecho, gracias a los esfuerzos de notables publicistas españoles y extranjeros. Pero no menos exacto que, aunque ciencia especial, necesita todavía de grande desarrollo, y pocos son los tratados en que no nos presente un estado de elaboración penosa y difícil. Y la divergencia de opiniones, que por sí sola mueve al estudio, impulsa cada vez más, por lo mismo que la política en los diversos países con sus interes (sic) y con sus pasiones llega a prescindir de los sólidos cimientos que la ciencia le proporciona, cuanto más de los que no ofrecen consistencia: siendo lo cierto, que sólo la ciencia con sus tranquilas soluciones, desalojando a la ignorancia de sus trincheras y haciendo desaparecer su imperio, que es el de la fuerza, podrá conseguir que, en vez de tener las cuestiones políticas el triste y funesto privilegio de decidirse en las barricadas o en los campos de batalla, se resuelvan definitivamente, como las demás, en la serena región de las ideas, en el animado, pero pacífico palenque de la discusión.

Entre los distintos asuntos que, dentro del círculo que me he trazado, pudiera escoger, considero que os inspirará sumo interés el sufragio popular, no sólo por lo estendido (sic) que se encuentra en la generalidad de las naciones, sino porque res- 
pecto a él se suscitan en nuestros días cuestiones muy nuevas, que ensanchan notablemente el campo de la investigación.

Vamos, pues, a examinar quienes deben de tener voto, la manera de que se emita con eficacia y el grado en que haya de poseerse, suponiendo adoptada legítimamente en un país una forma de gobierno, en la cual esté confiado el ejercicio de la soberanía a Cuerpos de elección del pueblo.

[2] Conformes con la opinión del R. P. Taparelli, y con la de los primeros publicistas de la escuela liberal, no consideramos el sufragio un derecho del hombre, por lo mismo que no conceptuamos la forma democrática la única legítima. Pero, sino (sic) admitimos como atributo de la personalidad del individuo el poder sobre otros, no por eso suponemos que el legislador sea árbitro de conceder o negar el voto sin sujeción a determinados principios, lo que equivaldría a sustentar que las leyes fundamentales escapan a la regla general aplicable a las más insignificantes, y que el presidente Montesquieu ha formulado con sencillez y precisión cuando dijo: "Afirmar que en la sociedad nada hay justo e injusto, sino lo que las leyes permiten o prohíben, vale tanto como asegurar que antes de que el círculo estuviese trazado no eran iguales todos sus radios". En Derecho político, de igual manera que en todas las ramas del Derecho, sobre la voluntad de los legisladores está la justicia, existe el orden, y el poder social no obra legítimamente en cuanto desconoce o desatiende las reglas inmutables del mismo: desde el momento en que esto haga resultará necesariamente violado el derecho individual, y como ha dicho Bossuet, no hay derecho contra derecho.

A la luz de estos principios creemos poder caminar con paso seguro y desembarazado por el ancho campo de la teoría del sufragio, libres de los peligros e inconvenientes a que conducen forzosamente los que, bajo una apreciación equivocada del hombre, le lisonjean con derechos que no tiene ni precisa, para retroceder quizá muy en breve como espantados de su propia obra, convertir en ilusión lo que no debieran concederle, y despojarle de aquello de que no debiera ser privado. Porque es de advertir que nadie como los que declaran el sufragio un derecho natural le mutilan luego, excluyendo de votar a clases enteras. Y, por el contrario, viendo en él, no el ejercicio de la soberanía, sino la elección de los que hayan de ejercerla, pierden su importancia los argumentos que contra su extensión se dirijen (sic), y sin obstáculo pueden entrar a emitirlo multitud de personas, a quienes un razonamiento apoyado en falsas premisas se lo niega.

Si el legislador al conceder el sufragio debe tener en cuenta la índole y tendencia del mismo y atemperarse a la justicia, en rigurosa consecuencia debe extenderlo lo posible. En efecto; si el sufragio es la designación por el pueblo de sus gober- 
nantes, el nombramiento de los más dignos del poder por su idoneidad para el desempeño justo y acertado de las funciones que le son propias, si el sufragio se considera como garantía eficaz para la organización de las Instituciones, de modo que respondan a las aspiraciones del país y en ellas se inspiren, si, por otra parte, todos los miembros de ese pueblo son iguales fundamentalmente, son personas y tienen sus aspiraciones, es indudable que todos deben elegir, y sólo los que de la plenitud de su personalidad carezcan, o de ella hubiesen sido privados en virtud de una sentencia condenatoria, serán los únicos a quienes la ley no deba atribuir la facultad de votar, porque, haciéndolo, faltaría a su propósito y hasta incurriría en inconsecuencia. Y no se crea que al discurrir de esta manera se olvidan las desigualdades que entre los hombres existen. Lo que se hace es no darlo todo a la desigualdad, de tal suerte que la igualdad sea una burla. Dando a todos lo que a todos debe darse, se puede y debe hacer en el grado que a cada cual compete.

Por lo demás, excluir del sufragio, después de calificarlo con el pomposo nombre de universal, a clases enteras, implica contradicción con decir que el pueblo elige. Gobiernos en que esto pasa podrán ser llamados populares, en cuanto que una parte del pueblo participa de la organización del poder. Pero, sólo convencionalmente puede admitirse semejante locución, que tanto dista de la realidad de la idea, la que supone, aun desechadas exageraciones absurdas, que no quedan excluidos de las funciones atribuidas a unos ciudadanos, ningunos otros que puedan ostentar análogos títulos, que pueden decirse capaces de la función que se les retira, con mengua de su dignidad, que también tiene su honor el desempeño de los cargos. Semejantes formas de gobierno son populares en el sentido en que se denominan así las de la antiguiedad, las decantadas democracias de la Grecia, en donde, mirada la sociedad en su conjunto y con imparcial criterio, no se encuentra en la vida pública más que la anulación de la mayor parte de las personas bajo un cuerpo de ciudadanos, que es preciso contemplar tan superficialmente que, a nada que profundicemos, ya nos sorprende la miseria, la degradación, la esclavitud. Estos gobiernos, como otros tantos de que posteriormente la historia nos da noticia, están muy lejos de constituir el ideal democrático.

Además de que las restricciones del sufragio envuelven un principio de injusticia, negando a ciertas personas indebidamente la facultad de hacerse oír por medio de sus elegidos, y falsean la naturaleza de la forma democrática, se oponen al fin principal que ella debe realizar, desmienten la mayor de las ventajas que su establecimiento debe proporcionar a los pueblos, cuál es el desarrollo de la inteligencia y de la actividad para el gobierno. Si los derechos políticos son como gran escuela en que las naciones aprenden a discernir sus verdaderos intereses y a llenar dignamente sus deberes, es forzoso reconocer la grande y evidente ventaja que 
habrá de producir, en un pueblo regido por una forma de las llamadas libres, iniciar al mayor número posible de ciudadanos, no sólo en el conocimiento, sino también en la práctica de la libertad política.

Mas, a pesar de reconocer la estensión (sic) del sufragio como regla general de las formas democráticas, nos encontramos con que, ora por las leyes, ora por eminentes publicistas, se sostienen ciertas limitaciones, a nuestro modo de ver injustificadas en la esfera científica, y de las que, por consiguiente, debemos ocuparnos.

[3] Hablemos en primer lugar de los procesados presos preventivamente. Basta fijarse en lo que es la prisión preventiva, para deducir, a nuestro juicio con evidencia, que no deben estar privados de votar. El que la sufre puede ser un inocente; por de contado, aún no se sabe si es criminal; no se le trate, por tanto, como si lo fuera: ¡Qué decimos! no se le trate peor que si lo fuera, pues es lo cierto que, por estar presos, quedan sin votar los que, condenados definitivamente y sufriendo la condena, podrían hacerlo por la índole de ciertas penas. Si el objeto de la prisión preventiva es asegurar el cumplimiento de las sentencias y evitar confabulaciones que pudieran preparar la impunidad, se obtiene perfectamente, sin privar del voto al preso; y el hacerlo sin necesidad es lujo de precaución, es quebrantar indebidamente la justicia del sufragio; y esto sin tener en cuenta los abusos a que se presta el subordinar el voto a un auto de prisión, siempre discrecional, por muchas que sean las garantías de que se le rodee. No diremos nada de la gravedad que estas consideraciones adquieren, cuando llega a darse el espectáculo de que, objeto de varios correos de un mismo delito y de un mismo decreto de prisión, no votan los encarcelados y sí los que mediante fianza obtienen su excarcelamiento. Si se quisiera argüir con el efecto que produciría ver salir de las prisiones escoltados a los votantes, contestaríamos que mucho peor sería verlos dentro privados de votar contra su voluntad, sin motivo suficiente. Además de que estas salidas podrían evitarse, cambiando la manera de votar, que, después de todo, es preferible que la forma de emisión se subordine a la facultad de emitir, a lo contrario. Si, por último, se quisiese invocar la independencia del elector, creemos que podría decirse que ninguna coacción más eficaz que la de la ley prohibiéndole en absoluto el voto. Para las influencias nocivas está la sanción penal; y, en el orden preventivo, una buena organización administrativa pone a cubierto, en cuanto puede desearse, la independencia del preso, contra las dañadas sujestiones (sic) que pudieran cohibirle. Y en esto debería pensarse, antes que castigar con la privación del voto al que, lejos de ser autor, es víctima de la coacción.

En gran parte son aplicables estas consideraciones a ciertos penados, a quienes se impide dar su voto, sin haber sido privados de él por la sentencia. Lejos de nuestro ánimo abogar por el crimen; pero, sí para el criminal queremos pena, pedimos 
en todo lo demás respeto a la personalidad del individuo. O se merece la pena de privación del sufragio, y esto es cuestión de derecho penal, en cuyo caso debe cumplirse la condena, o no se la merece, y por tanto no se la impone; y entonces, es una inconsecuencia obligar al ciudadano a sufrirla de hecho, es una injusticia, porque el reo continúa en la plenitud de los derechos que las leyes le declaran, mientras que por su culpabilidad no se le sentencia a perderlos. Estas consideraciones, a que por lo general no se atribuye la importancia que envuelven, efecto de la indiferencia habitual o de circunstancias que los penados tienen hacia la política, y por otra parte, del desfavorable concepto con que por lo común es mirada la población de los establecimientos penitenciarios indistintamente, se presentan en su verdadero valor, colocadas las cosas en su terreno propio, destituido el ánimo de pasión.

[4] Algo de penalidad se deja ver también en la exclusión del sufragio de los deudores a fondos públicos. Dura demasiado no parece esta exclusión, aun cuando de ella no pudiera decirse que habrá de castigar comúnmente omisiones involuntarias para los efectos de la criminalidad. Medios sobrados tiene la Administración para apurar a los morosos, hasta hacer efectivo el pago, sin necesidad de acudir a la privación del voto, que por lo innecesaria, se hace de todo punto injusta. Empléelos, pues, a costa del deudor, y bastante penada le queda por este medio su morosidad. Y si, después de todo, no realiza su crédito, absténgase de oponer en compensación la negativa del sufragio, que no es deuda de igual naturaleza, para que pueda compensarse. Y esto, mirando en el sufragio las cosas como pasan, solamente la parte grata para el que lo posee; que de estimarlo en su verdadera naturaleza; de ver en él principalmente, como debiéramos, una carga social, dicho se está cuan inoportuno sería excitar al cumplimiento de un deber, eximiendo del de otro.

La excepción propuesta relativamente a los que nada contribuyen a los fondos del Estado, apenas debe ocuparnos; porque, aun admitida, no hay términos hábiles para aplicarla, desde el instante en que el impuesto desciende a las clases menos ricas, según la justicia lo aconseja, y los estadistas más competentes lo desean. Otórguese el sufragio y no se perdone medio para conseguir que contribuya el que deba hacerlo, y en ello el Estado usará de su pleno derecho; mas no se cercene a los ciudadanos la facultad de votar como precio de una redención del tributo, tanto más injustificada, cuanto que, si suponemos al país bien maduro para la forma democrática adoptada, las dificultades para la realización de las cargas pecuniarias, no serán ciertamente insuperables.

Es otra exclusión controvertida la de los concursados y quebrados. Sin rebajar en un ápice lo feo e indigno que pueda haber en su conducta, quisiéramos, no obstante, que ni en un ápice tampoco se impusiese por una ley electoral el castigo, que 
sólo a la penal toca establecer y a los tribunales aplicar. Y si en los casos en que no haya existido criminalidad, se acude a la dependencia en que el hombre en semejante situación queda constituido, no creemos que sea razón suficiente. Su dependencia será la de cualquiera que deba, y sin duda que tacharíamos de injusta la ley que a todo deudor conocido privase votar. Si los débitos absorben por completo su fortuna, su condición será la del que carece de bienes, y en su favor son aplicables las consideraciones antes hechas en defensa de la extensión del sufragio. De modo que siempre resulta injustificada su exclusión.

[5] Son los pobres otra de las clases, triste objeto de la duda. Dejemos ya aparte a los válidos, que por motivos transitorios, una crisis, por ejemplo, se ven reducidos a pobreza temporal; pues a semejantes personas sería el colmo de la iniquidad retirarles el sufragio, aun suponiendo que la torpeza o negligencia del gobierno no fuese la causa productora de su desgracia. Concretándonos a los pobres inválidos, no parece injusto e inhumano el rehusar el concurso de estos seres desgraciados, acrecentar su infortunio, negándoles por su situación, y sólo por su situación, una prerogativa ( $\mathrm{sic}$ ) que se supone extendida en toda la masa social, que no se niega al que, tan pobre como ellos, no hace público su estado, recibiendo el socorro de particulares o asociaciones privadas, y de la cual gozarían ellos mismos a no ser pobres; pues, que fuera de esta circunstancia, partimos de la hipótesis de que por su aptitud y moralidad no son indignos del sufragio. Siendo esto así, e indudablemente tiene que ser en todo país bien organizado, en que no anden confundidas la vagancia y la desgracia, el pobre votará con igual conciencia que el no pobre; y en muchos casos, persona de buenas condiciones, votará con mucha mayor competencia. $\mathrm{O}$ hay criminalidad en la pobreza, y entonces comiéncese por depurarla en los tribunales y discútase la pena que se pretende imponerle, o, si rechazamos tan funesto pensamiento, respetemos al pobre y que el respeto no sea vana palabra, y en vez de arrojar sobre él desconfianza y tormento, alentémosle, y no pensemos sino en ayudarle, sin rebajar en lo más mínimo la plenitud del derecho que al dejar de ser rico disfrutaba.

No se leen sin profunda pena las consideraciones que, impugnando el voto de los que están a cargo de la parroquia, hace el esclarecido publicista inglés Stuard (sic) Mill. "El que no puede sostenerse con su trabajo, dice, no tiene el derecho de servirse del dinero de otro. Desde que llega al punto de depender de los demás miembros de la comunidad para su subsistencia, abdica su derecho a ser tratado como antes. Aquéllos a quienes debe la continuación de su existencia, pueden reclamar con justo título la dirección exclusiva de los negocios generales a los que él en nada contribuye". Ni el voto es el derecho de servirse del dinero ageno (sic), ni aun 
cuando bajo cierto punto de vista pudiera haber algo de exactitud en esta idea, sería concluyente. No sería otra cosa que el influjo una clase en daño de otras, contra lo cual el mismo Stuard (sic) Mill nos da el remedio. Además de que semejante razonamiento descansa en la presunción inadmisible de que, con la riqueza, pierde el pobre el sentimiento moral. Esto podrá sospecharse en un país dominado por el principio del interés, por el frío móvil del cálculo egoísta. En donde el sentimiento católico prevalezca vendrá en apoyo de la personalidad del pobre, presentándole a los ojos del rico acreedor a su limosna, pero no degradado, ni prostituida su conciencia. La abdicación que al pobre se atribuye gratuita, y contraria a la base de que partimos, que es que el pobre quiera votar. Y, por fin, la dignidad humana se hiere profundamente al oír que, el que sostiene al pobre, puede reclamar con justo título la parte de intervención del mismo en los negocios generales. ¡Donosa beneficencia la que lleva como cortejo inseparable la inhabilitación política del socorrido!

Se ha dicho también que el pobre no debe votar, porque no es independiente. Tan independiente es el pobre como el jornalero, cuyo voto no se impugna, que con su laboriosidad gana el sustento, y nada más que el sustento, que aquél recibe del Estado. Es más, no todos los pobres, según dejamos indicado, son de una misma categoría; porque la desgracia afecta sin distinción a todas las clases, y la imprevisión no es peculiar de determinado género de individuos; así es que entre los pobres, aun siéndolo todos, median diferencias por razón de sus antecedentes, que deben ser atendidas al juzgar sus cualidades. Sobre todo, si el pobre reúne idoneidad y moralidad para votar, estas cualidades garantizan su independencia, de igual manera que la de cualquier ciudadano. No es de los pobres seguramente de quienes con mayor razón puede decirse que venden su conciencia a torcidas influencias. Y hablamos de éstas porque a las influencias legítimas, racionales, claro es que todos debemos sujetarnos, y, lejos de constituir una coacción censurable, son a no dudarlo compatibles con un voto consciente.

[6] Es también animada la discusión respecto al voto de los que no saben leer ni escribir. Admitamos lo que de ordinario sucede, que no es ciertamente lo que Schedo-Ferroti dice de los rusos, que, después que aprenden a leer y a escribir, son más brutales y tienen menos moralidad que antes de aprender; y si, por el contrario, que el saber leer y escribir, ensanchando considerablemente los medios de comunicación con nuestros semejantes, es el auxiliar poderoso de nuestro perfeccionamiento, y por decirlo así, la base del desarrollo intelectual del hombre en un grado superior. Pero, aun siendo esto así, no es menos cierto que los ignorantes en lectura y escritura tienen, sin embargo, comúnmente en un país adelantado, una instrucción regular, debida al trato frecuente con sus conciudadanos, a la enseñanza de viva voz 
y otros medios de ilustración, que influyen mucho más que el saber leer y escribir, que al fin no es la instrucción, sino facilidad para adquirirla, que puede o no aprovecharse. Es menester no olvidarse de que no se trata de gobernar, sino de elegir, cosa que por muy relacionada que se halle con la anterior es, no obstante, muy diversa. No se requiere, en efecto, igual instrucción para regir un Estado, que para escoger los que considere que mejor podrán hacerlo, para lo último puede poseer la instrucción indispensable, sin saber leer ni escribir, en una nación civilizada. El argumento empleado por Stuart Mill, cuando dice que falta al sentido común el que sostiene que debe concederse el poder sobre otro, el poder sobre la comunidad, a gentes que no han adquirido las condiciones más ordinarias y las más esenciales para cuidar de sí mismos y para dirijir (sic) con inteligencia sus propios intereses y los de las personas que les tocan de cerca, adolece del error de creer, en primer lugar, que el voto es el poder sobre otro, el poder sobre la comunidad, contra lo que él mismo en otros pasajes nos enseña; y, además, lleva las cosas a un terreno inadmisible, sustentando que es esencial para el cuidado propio y dirección inteligente de los intereses el saber y leer y escribir, contra lo que los hechos nos revelan ordinariamente. Los que carecen de estas nociones pueden muy bien reunir circunstancias en estremo ( sic) atendibles bajo otros aspectos; por ejemplo, la riqueza, para que se les oiga, lo cual constituye un poderoso motivo más, para que no se excluya en masa a todo aquél que no sepa leer ni escribir, y sólo por esta razón.

En defensa de la exclusión que nos ocupa se alega la conveniencia de fomentar por su medio la instrucción. Pero creemos que a esto puede oponerse que el fomento debe procurarse, mas no por medios injustos, cual viene a serlo la privación del sufragio, si destituida de otro fundamento, se la emplea solamente por vía de estímulo para la consecución de un fin, por recomendable que él sea. Y, aun mirada la cuestión bajo este punto de vista, se nos figura que, lejos de cooperar la privación del voto a la instrucción, la retrasa. De ordinario, sólo por la esperanza del voto no se aprende a leer y escribir, y en muchos casos esta perspectiva será un motivo para continuar el que no sabe en su situación. Y llamándole a votar, sentirá con más viveza que antes la necesidad de medios de comunicación en la nueva vida que se le abre. De la lectura y escritura nos parece que puede decirse lo que un precioso instrumento, que se oxidará, si no hay ocasiones y voluntad de usarlo, siendo preciso que de antemano o simultáneamente se proporcionen éstas. Finalmente, considerar la exclusión como castigo de la indolencia es inicuo, como dice perfectamente el distinguido publicista español Sr. Colmeiro, porque la pena no afecta al delincuente que es el encargado de la educación de los menores, sino a estos que son los que la sufren. En este modo de racionar, además, viene a aplicarse una pena a un hecho, que no debe considerarse verdadero delito. 
[7] Llegamos ya a la exclusión más numerosa, y si se quiere la menos debatida; pues, aún hoy, apenas hay publicistas que a ella se opongan. Ya no es ni la moralidad, ni las condiciones económicas, ni el carecer de nociones de lectura y escritura lo que va a ocuparnos, aun reuniendo las demás condiciones, se pretende excluir de votar a las mujeres, siendo su sexo la única causa para ello.

Desde luego no se comprende que esta exclusión se sostenga por los que consideran el derecho de votar como uno de los inherentes a la personalidad humana. O se la niega a la mujer, o hay falta de lógica en no reconocerle aquel atributo. Y no se diga que, aun teniendo el derecho, le falta capacidad para ejercerlo; lo cual sería aplicable a algunas o a muchas, mas no a todas; que esto equivaldría a sostener que por la naturaleza poseían un derecho, de cuyo ejercicio eran naturalmente incapaces. Aceptado el principio, las consecuencias legítimas se derivan forzosamente. Y con razón Duvergier de Hauranne ha creído ver en la excepción de la mujer, que él califica de impuesta por la moral y el sentido común, el pelo secreto que hace saltar el hierro más sólido y más puro, la conclusión que reduce a nada la doctrina del sufragio como derecho natural. Nosotros, sin admitir ni el derecho ideal que este célebre escritor francés rechaza, ni el positivo que el mismo admite equiparándolo al de propiedad, creemos que, en el terreno científico, no puede ser objeto de una oposición seria y fundada el sufragio de la mujer.

No se nos ocultan las impugnaciones sarcásticas de muchos notables escritores que, pretendiendo arrojar el ridículo sobre la mujer mezclada en política, demuestran claramente la convicción que acerca del asunto tienen formada. Ni menos dejamos de conocer el juicio de la misma parte interesada, la manera con que las mujeres mismas, en casi su totalidad, califican la intervención de su sexo en las funciones de ciudadanía. Pero todo esto, que tendría una importancia suma y decisiva, si se tratase de legislar para un país determinado, porque nadie duda que sería intempestivo establecer un derecho que a la mayor parte y la no menos competente inspirase una sardónica sonrisa, y a las que debieran ejercerlo un soberano desprecio; en el terreno de la ciencia nada vale; puesto que, porque las mujeres quieren o no votar, porque los hombres se ocupen o dejen de ocuparse de la cuestión, no por eso dejará de ser justo que las mujeres tengan dicha facultad, que es de lo que se trata.

$\mathrm{O}$ son falsas las razones que en apoyo de la extensión del sufragio alegan sus sostenedores, o no es posible negarlo al sexo femenino. La justicia electoral, las ventajas de la forma democrática, que se invocan respecto al hombre, tienen aplicación cumplida a la mujer: ella es igual al hombre en el recto sentido de la palabra igualdad: ella es susceptible de perfeccionamiento, como el hombre puede serlo. ¿Por qué, pues, no se ha de atender a su igualdad y a su perfectibilidad? "Todos los seres humanos, dice Stuart Mill, en defensa del sufragio de las mujeres, 
tienen el mismo interés por conseguir un buen gobierno, su bienestar a todos afecta igualmente, y necesitan de igual modo del voto, en cuanto puede asegurar su parte de beneficio. Y si existe alguna diferencia, las mujeres necesitan de él más que los hombres, pues que, siendo físicamente más débiles, dependen más de la ley y de la sociedad para su protección”. La moralidad, condición importantísima del voto como de todos los autos humanos, aun más que el interés en que el citado autor se fija exclusivamente, no es privilegio del hombre. Y si la forma democrática supone la concurrencia de todos a designar los que gobiernen, no hay, ciertamente, porque excluir de entre todos a la mujer, que no tiene, ni por interés, ni por moralidad, peores títulos que los que el hombre puede invocar.

Sucede con el voto de la mujer lo que con otros tantos diversos conceptos, en los que, desconocida, su dignidad en un principio, se la apreció después en su justo valor. En la familia estaba absorbida su existencia por el hombre, y merced al influjo del catolicismo ha ido creciendo hasta colocarse a su lado. En el orden industrial y a fines del siglo pasado Jovellanos, Campomanes y la generalidad de los economistas consideraron justamente el trabajo de la mujer como un elemento poderoso para la prosperidad de la industria en sus múltiples y variadas ramas; y las leyes le permitieron el ejercicio de muchos oficios, de que los gremios la excluían. Hoy las mujeres obtienen títulos académicos en las naciones más adelantadas, se distinguen por sus producciones científicas y literarias y ejercen con elevada reputación multitud de profesiones, hasta aquí monopolizadas por el hombre. En el mismo orden político, intervienen y su mediación es reclamada sin distinción de partidos si (sic, ni) de opiniones; y, así las vemos, por ejemplo, dirigir exposiciones a las cámaras apoyadas por respetabilísimas personas. Y si actualmente no podemos decir, como poco ha, y en otras naciones acontece, que el país está gobernado por una mujer, podemos con el corazón henchido de noble orgullo proclamar muy alto, que el más glorioso soberano que ha tenido esta nación, ha sido la mujer que en América, en Granada y en otros tantos hechos de su reinado dejó escritos con caracteres indelebles la actitud de su sexo para las empresas más arduas. Guardémonos, por tanto, de conceptuarlo indigno cuatro siglos después, no ya de tanta magnanimidad, pero ni aun de depositar en una urna la cédula electoral que al hombre menos apto no se le rehúsa.

En favor de la negativa se alega que el papel natural de la mujer es educar honestamente a su familia y dedicarse a las labores domésticas. Pero esta misión importantísima, que sin duda le está principalmente encomendada, ni afecta a todas las mujeres, ni a una sola durante toda su vida, ni aun en el caso en que deba realizarla, absorbe absolutamente su actividad, de tal modo que no le permita como compatible el desempeño de la función de que tratamos, que tan fácilmente puede ser 
ejecutada. Por muy ocupada que en los negocios de su casa y en el cuidado de su persona y familia esté la mujer, más lo está sin duda la clase jornalera, que para vivir necesita trabajar incesantemente, sin que le queden libres los ratos de que de ordinario dispone aquélla, y por eso no se la excluye.

Si se quiere decir que sólo las labores del hogar doméstico le son peculiares, creemos se puede contestar que, ni la ley es la llamada a señalar al individuo los trabajos en que haya de ocuparse, ni tampoco es exacto que la mujer haya nacido exclusivamente para regir el interior de su casa, para hilar y coser las ropas de la familia. Protestan muy elocuentemente contra este razonamiento, sin salirnos de nuestra patria, Santa Teresa de Jesús, Beatriz de Galindo, Luisa y Ángela Sigen, Catalina Badajoz, Luisa Medrano, la duquesa de Béjar y otras tantas mujeres ilustres que pudiéramos citar, tipos de galanura y novedad en el campo de las letras y de sublimidad en la región del arte.

Verdad es que la dificultad queda en pie, a los ojos de los que, si bien admiten, y aun desean, que la mujer se mezcle en política, difieren únicamente en cuanto al modo, pues quieren que esta influencia se ejerza sin traspasar el límite de las relaciones privadas. No acertamos a explicarnos semejante modo de discurrir. Si la mujer es digna e idónea para pensar y ocuparse de política; si se afirma, como lo hace Edmond du Temple, que su interés se lo demanda y que su intervención puede engendrar excelentes resultados; si se quiere, según la frase de nuestro comprofesor el Sr. Sanromá, a quien me complazco en recordar como catedrático en esta Universidad, que la mujer, porque le conviene y porque nos conviene, ponga sus delicadas manos y su agudo ingenio en los problemas de quintas, esclavitud y otros, que tienen su raíz en la política; después de todo eso, hay a nuestro juicio, una flagrante injusticia y una marcada inconveniencia, en impedirle que, con su voto, pueda tener en los parlamentos quien lleve su voz en el solemne instante, en que tan trascendentes cuestiones se resuelvan.

Ni perjudicaría a la tranquilidad de la familia la facultad de votar de la mujer, como por algunos espíritus, no sé si demasiado débiles o demasiado fuertes se supone. Si por fortuna el hombre y la mujer pensaban de igual manera, nada había que temer. En caso de divergencia de opinión, o suponemos que la cosa sería llevada razonablemente, y entonces nada más ventajoso para la mujer, ni más conforme a su dignidad, sin menoscabo de la conveniencia y del honor del sexo masculino, que poseyese ese algo más de que hacer gracia a sus parientes, que se presentase ante su marido con esa influencia sobre el mundo exterior, que aumentando su valor personal inspirara respeto; o admitimos que se ejerciese presión o violencia por alguna de las partes, si era por la de la mujer: ¿estaremos en el caso de decir al hombre los medios de defenderse? Y si por la del varón: ¿no tendríamos que recor- 
dar la fábula del lobo y el cordero, si por medicamento heroico de tales dolencias de familia, se hubiese de propinar precisamente por aquél a la mujer cohibida la prohibición del voto?

Ni tampoco habrían de padecer las costumbres públicas, porque, verificándose esta revolución política, que así podríamos llamarle, en la mitad más bella del género humano, tomase parte en una elección. Las cualidades características de la mujer, su virtud, su pudor, debemos de creer, que produjesen los mismos buenos efectos que en las reuniones a donde concurre. En una sociedad corrompida, bien podría sospecharse que la reunión de los diferentes sexos, en política, como en otros negocios, sería perniciosa. Cuando la dignidad de la mujer se realza, y el decoro de la que es honrada se sostiene por el sólo prestigio de su virtud, cuando entre las mujeres hay Hermanas de la Caridad, con las cuales la juventud de las naciones aprende a conocer las excelencias del sexo opuesto, y a respetarlo hasta en medio de la vida libre de los campamentos; bien se puede esperar que andando el tiempo, tanto como no dudamos que tendrá que andar, para que cuanto decimos deje de considerarse música celestial, preciosa, pero fuera del alcance de los mortales, el progreso moral, la verdadera civilización, calcada sobre una educación completa de ambos sexos, presentará asequible y viable un hecho, que, por ahora, a tantos parece, a la par que una ridícula extravagancia, o un dorado ensueño, una reforma peligrosa e inmoral.

[8] Acabamos de impugnar las exclusiones del sufragio, extendiéndolo de tal suerte que, según al principio indicamos, sólo quedan privados de votar los que carecen de la plenitud de su personalidad; v.g. los menores o los mentecatos; y los penados con la privación del mismo. Mas, es lo cierto que, aun extendiendo el sufragio de esta manera, continuando el sistema electoral aplicado hasta el presente, no por eso se consigue que la elección sea, como la índole de la forma democrática lo demanda, la designación de los gobernados, de modo que cada individuo pueda ver en el manejo de los destinos de la nación a la persona que votó, y de la que se prometía la realización de sus aspiraciones. Fijémonos sino en lo que acontece. Al verificarse una elección, luchan diferentes opiniones; una lleva la mayoría y ella nombra los diputados, que se llaman del país, pero que, lejos de responder al pensamiento de las fracciones vencidas, le son enteramente opuestos, sin que ni ellas, ni los electores independientes, tengan quien lleve su voz, para contrarestar (sic) la adversa. Por este procedimiento el sufragio de las minorías se hace de todo punto ineficaz, lo mismo que si se las declarase incapacitadas para votar; y la forma democrática se hace ilusoria, o por lo menos sólo en parte se realiza su idea: no es el gobierno del pueblo por el pueblo, en lo que estas voces tienen de verdad, sino 
el gobierno del pueblo por una parte del pueblo; parte que puede llegar a ser reducísima (sic), como sucedería si estuviesen casi equilibradas las fuerzas y, por consiguiente, la victoria de la mitad más uno, y aun de menos, cuando bastase una mayoría relativa, anulase la influencia de las fracciones restantes vencidas. Y no se objete que, por el fraccionamiento del cuerpo electoral en colegios, los vencidos en el uno pueden ser vencedores en el otro; porque, esto, posible y aun frecuente en donde los partidos o clases reúnen todos gran número, no sucedería si la clase predominante formase una mayoría inmensa, que entonces su preponderancia se haría sentir indudablemente en todas las secciones, dejando a lo más alguna que otra excepción insignificante. Y de todos modos, aunque las distintas opiniones reinantes en la sociedad lograsen tener algún órgano en las esferas gubernamentales, siempre sería una verdad que para multitud de ciudadanos, alguna vez más de la mitad del cuerpo electoral, era una falaz ilusión la representación popular; pues que, no sólo carecían de representante de su nombramiento, sino que, a su despacho, tenían que verse representados quizá precisamente por sus más encarnizados enemigos políticos.

Para evitar estos inconvenientes, con otros de gravedad suma que conciernen a las cualidades del cuerpo elegido, ilustres políticos de la Inglaterra presentaron en diferentes épocas diversos sistemas encaminados a poner término a la proscripción de las minorías. Su voz se hizo sentir en las demás naciones, en la nuestra ha encontrado eco más de una vez en las cortes, y en la prensa la han sostenido y proclamado beneficiosa y merecedora de ser acogida por la ley, escritores tan notables como D. Luis María Pastor.

Propuso el estadista del Reino Unido Lord John Russell el voto por lista y por colegio, no pudiendo cada elector inscribir en su papeleta sino una parte de los diputados correspondientes a su circunscripción, por ejemplo, de tres, dos o uno, de un modo análogo al que se usa en España para elegir las mesas.

Creyendo mejorar el sistema, propuso M. James Garth Marshall que el elector fuese árbitro para adjudicar un número de votos igual al de los diputados del colegio, v.g. tres, entre los mismos, según mejor le pluguiese, pudiendo dar hasta los tres a una sola persona, sin mencionar las demás.

Métodos mejores que nada, como dice Stuart Mill, que por lo mismo considera muy censurable no se les hubiese puesto en ejecución, una vez que ambos obedecen al verdadero principio y habrían preparado la senda de una aplicación más completa. Pero que, sin embargo de sus brillantes apariencias, tienen aún en teoría, y el primero más que el segundo, el inconveniente de no asegurar a las minorías sino una representación arbitraria e inexacta; y, en los casos en que la mayoría de un colegio exceda en un solo voto de las dos terceras partes del total de electores, fra- 
casan por completo, pudiendo aquélla formar dos grupos, los dos más numerosos que la minoría, el uno que votase la parte de diputados que llamaremos de la mayoría, y el otro la restante reservada a las minorías, que por aquella vez quedaban sin representante.

Estas dificultades desaparecen en el sistema de M. Tomás Hare. Según él son abolidas las circunscripciones electorales, y el país en masa constituido en colegio único nombra sus diputados. El elector inscribe el nombre de su candidato en una papeleta, y la entrega en una sección de las en que el país está dividido, sólo para el acto material de la recepción de votos. Cada sección remite los recibidos a una junta central, que verifica el escrutinio y proclama el resultado de la elección. El ciudadano nombra a quien quiere, sea o no de su localidad, y los nombrados que obtienen votación suficiente, cualquiera que sea la sección o secciones en que la obtengan, son diputados de la nación, y no de lugar determinado. El número de votos necesario para constituir diputado se fija de antemano, dividiendo el total de electores por el de miembros que se señale para la asamblea, y el cociente será el número buscado. Desde el momento en que un sujeto lo reúne en su favor, ya no se toman en consideración los demás votos que pueda tener. Y para que los que han emitido estos votos sobrantes y perdidos, y del mismo modo los que inscriben en su papeleta un nombre que no llegue a reunir el número de votos necesario, no queden privados de representación, se autoriza a los electores para inscribir sucesivamente varios nombres, a condición de que sólo uno ha de surtir efecto. La preferencia respectiva entre los votos reunidos por un candidato en mayor número del prefijado puede resolverse empleando diversos medios, que ya son cuestión de detalle, como otras tantas que se ofrecen, y a las que no podemos descender en esta ocasión. Las operaciones electorales se llevan con la mayor publicidad, facilitándose la acción popular para la denuncia de los excesos o errores que se cometan.

Por esta lijerísima ( $\mathrm{sic}$ ) reseña se puede comprender que este sistema contribuye mejor que ningún otro a dar verdad a la representación popular, eficacia al sufragio. El plan de Hare asegura representación, no sólo a los grandes partidos y a las grandes minorías de sección, sino también a cualquiera minoría que cuente en todo el país con el número de votos preciso para elegir diputado, conforme a la regla arriba enunciada. Y ningún elector será representado nominalmente por quien no eligió, como hoy sucede, a no ser aquél que se haya fijado exclusivamente en un candidato que no llegase a conseguir en la nación entera la cuota de votación indispensable, lo que jamás podrá evitarse.

De otras ventajas muy importantes que proporciona, facilitando la entrada en las cámaras a hombres notables, estimulando a las minorías a fijarse en personalidades célebres, obligando a las mayorías a recomendar hombres distinguidos y, por con- 
secuencia, realzando la capacidad de las asambleas y haciendo que las ideas del mayor número tengan que luchar con las del número menor, pero de mayor peso, así como de los inconvenientes que se le atribuyen, de ser impracticable, de ser demasiado nuevo, de prestarse a gravísimos fraudes, de retirar a la representación el carácter local y de proscribir la lucha de los partidos, no debemos ocuparnos porque nos distraería de nuestro objeto, que es hablar del sufragio, no de la forma democrática en general.

De propósito, no obstante, los hemos indicado, para que, con lo que antes dijimos, se deje ver con evidencia que si el sistema de Hare no ha logrado todavía en las elecciones públicas su planteamiento, ni en las regiones de la ciencia una aceptación unánime, ni aun de los que consideran como última palabra de la ciencia la representación de las minorías, no por eso deja de ser merecedor de un detenido estudio, al que también no puede menos de impulsar a todo espíritu exento de pedantesca presunción, o de punible indiferencia, el que una de las primeras figuras, entre los tratadistas del derecho público no vacile en calificarle "del más grande de los progresos que hasta el presente se han hecho en la teoría y en la práctica del gobierno".

[9] Demostrada ya la extensión del sufragio y averiguado el modo de que no sea ilusorio el de las minorías, nos queda otro punto importantísimo que tratar, único preservativo contra los inconvenientes a que pude dar margen la intervención popular en las condiciones expuestas, y que la representación de las minorías, por sí sola, puede precaver en en (sic) parte, pero no evitar completamente. Aludimos al grado de influencia electoral, a la extensión del sufragio relativamente al individuo que lo posee.

Ni la forma democrática, ni los buenos resultados que de ella puedan derivarse, exigen para ser una verdad, que el voto de cada ciudadano haya de ajustarse a una medida absolutamente igual para todos, e inalterable. Ni podía suceder de otra manera, siendo cierto que las formas de gobierno no pueden nunca hallarse en oposición con la naturaleza del ser a que se refieren. Los hombres no hemos sido vaciados todos de un mismo molde, ni hechos bajo un mismo nivel, y así en lo físico como en lo intelectual y en lo moral nos separan grandes y marcadas diferencias, sin que por ello se destruya el principio de la igualdad bien entendida. Estas diferencias se han de hacer sentir por necesidad en el sufragio, de igual modo que en los demás actos del individuo, reflejando la variedad de opiniones, y, apreciadas en su justo valor, deberán producir naturalmente el resultado de que la que más vale ser reputada de mayor mérito y obtenga mayor influencia. La dignidad del hombre podría creerse con razón ofendida, si no se le cuenta por nada, no se diría justamente lastimada, por ver que se confiera a otros un voto más poderoso, por efecto 
de una mayor capacidad, y nadie que no sea un necio, y un necio refinado, puede quejarse, porque se atribuya al deseo y a la opinión de otro una consideración distinta que a los suyos. Debemos, por consecuencia, convenir en que el legislador que al regularizar el sufragio se atemperase a estos principios, lejos de ser caprichoso y arbitrario, se conformaría con la marcha natural de los negocios humanos.

Esta diversidad de influencia electoral, que según vemos, es aconsejada por la más estricta justicia, se hace por otra parte indispensable para proveer en lo posible a los males que del sufragio igual y sin restricciones, principalmente si se le emite por el sistema de Hare, pudiera ocasionarse. Es indudable que las asambleas son por lo común el reflejo del cuerpo electoral y la mayoría de electores de una opinión determinada produce generalmente una mayoría proporcionada entre los elegidos, por lo que resultará, dadas aquellas condiciones, que el número será el que decida de la suerte del país, llevando quizá el poder a manos de las clases menos idóneas para su desempeño y con intereses peculiares, a cuya satisfacción exclusiva se consagrarán con perjuicio evidente de los contrarios. No es esto decir que por fuerza haya de suceder así. Es indudable que al pensar de esta manera, se camina bajo la impresión de la desconfianza que produce el examen imparcial de nuestra condición y la esperiencia (sic) de los diversos tiempos y países. Por lo demás, no puede negarse que, obedeciendo estrictamente a su conciencia los electores y sofocando la voz de la pasión o de intereses egoístas, la elección podría dar, sin precauciones legales, los mejores resultados. Pero, debiendo atemperarnos a la marcha ordinaria de las cosas, porque precisamente por la posibilidad de los abusos se estudian las formas más adecuadas para evitarlos y sin forjarnos la ilusión engañosa de que ellas sean la panacea única contra los excesos de la inmoralidad, que tienen su curación radical en otro medio, del que desgraciadamente no nos preocupamos cual se merece, demasiado encadenados a las exterioridades, de todos modos, se hace indispensable asegurar, hasta donde sea dado, la inteligencia y la capacidad en el gobierno, contra los obstáculos que pudieran oponerse a su libre acción.

Con este fin, y partiendo de la base de justicia arriba expuesta, en nuestros días acaban de presentarnos sus sistemas, en el fondo conformes aunque algún tanto diversos en su desenvolvimiento, el publicista Mill, a quien por precisión tuvimos que recordar a cada instante, por la manera tan nueva como magistral con que ha tratado estas materias, y el no menos digno de deferente consideración James Lorimer. El voto plural y el voto cumulativo son el pensamiento capital de sus teorías, asegurándonos el primero con un tono de persuasión íntima "que en esta dirección se halla el verdadero ideal del gobierno representativo», a lo que añade «que encaminarse a este punto por las mejores combinaciones prácticas que pueden hacerse es preparar el verdadero progreso político". 
En el sistema de Mill las personas que por diversos medios, que menciona, justifiquen su mayor aptitud, tendrán en su consecuencia mayor número de votos. En la necesidad de que la influencia superior de determinados individuos se confiera, según motivos que puedan ser comprendidos, y cuya justicia pueda distinguirse fácilmente, propone como criterio de preferencia la superioridad intelectual, no aceptando la riqueza, por creer que no siempre anda unida a aquélla, y que, por el contrario, rara vez el que ha adquirido cierto grado de instrucción puede asegurarse un grado de elevación análogo en la escala social, y, principalmente, porque considera que no realizaría el efecto deseado, por el celo y rivalidad que inspiran los ricos a los que carecen de fortuna, lo cual no acontece cuando la superioridad se funda en consideraciones personales. Y si bien desciende a sostener que al maestro de una industria se le dé mayor influencia que al aprendiz; que a un distinguido abogado, a un repúblico eminente se le tenga en más que a los que ejercen oficios insignificantes, que otro tanto se haga con aquéllos que ante tribunales bien organizados den pruebas de idoneidad, siempre partiendo de la base de que todos indistintamente aun los más pobres puedan obtener estos títulos que llevan anexa la preferencia, no lo hace más que con el simple objeto de esclarecer con indicaciones su pensamiento fundamental, como que protesta terminantemente que no quiere quedar ligado por proposiciones particulares emitidas, cuando aún no ha llegado a ponerse en ejecución su plan.

Más concreto el profesor Lorimer, apreciando la sociedad dinámicamente y no numéricamente, según feliz expresión, aspira a fotografiarla en el gobierno, como dice Duvergier de Hauranne. Y organizando sobre esta base el poder, conceptúa indispensable se fijen diversos elementos determinantes del derecho de votar, y que a cada ciudadano se le confieran los que le correspondan, sumados los distintos conceptos que en él concurran. De esta manera, la ciencia, la riqueza, la posición social, los servicios prestados, la edad, en una palabra, todo lo que puede contribuir a la importancia y valor de una persona, viene a servir para fijar la medida de su sufragio, pero no de tal suerte que, a la manera de las centurias de Servio Tulio, se formen clases propiamente dichas, encerradas cada una dentro de sus fronteras y con determinada influencia peculiar en los negocios públicos, sino disfrutando cada ciudadano una dosis, por decirlo así, de intervención política proporcionada a sus distintas cualidades, dosis variable en el curso de su vida con las condiciones que deban influir para el voto.

Ambas teorías seductoras en el terreno de la ciencia ideal y de la justicia pura, ofrecen para la práctica dificultades gravísimas, si se las ha de plantear con la extensión y eficacia que su pensamiento entraña. Aun suponiendo que las naciones 
se dedicasen a adoptarlas, dispuestas a hacer cuanto exigen y a abstenerse de todo aquello que pudiera comprometer su buen éxito, seguramente que habrían de encontrar entorpecimientos, a pesar de su buen deseo, tratando de fijar límite a la pluralidad del voto, de señalar el valor político de los ciudadanos, si así podemos llamarle, y las alteraciones que debiese esperimentar (sic), en la necesidad imprescindible de verificarlo juzgando por signos exteriores, únicos susceptibles de apreciación en la esfera del derecho.

Pero, si esto es un motivo serio para que los legisladores se abstengan de plantear una reforma prematura e impremeditada, lo cual sería temerario y en extremo perjudicial, no lo es de ningún modo para que se la abandone en el campo especulativo como utopía, a pretesto (sic) de oscuridad o insuficiencia, a la manera que lo verifica algún escritor de gran nota, optimista por demás. Sin descender a un examen minucioso y aislado de cada sistema, mirada en conjunto la idea que en ellos domina, inspira indudablemente un asentimiento racional, y su aplicación de ninguna manera se presenta imposible, siquiera sea con imperfecciones que nunca faltan en las obras de los hombres. El criterio de autoridad robustece este modo de pensar; porque, es de advertir, que los publicistas de la Inglaterra suelen ser tan dogmáticos e intrépidos en el dominio del pensamiento, como circunspectos y prudentes en las cuestiones de legislación, sin que por lo regular su genio ahogue el sentido práctico que les caracteriza. Y al ver que sin ocultar las dificultades de sus descubrimientos, los sostienen con fe y con convicción profunda de que su influjo será benéfico, hasta el extremo de remediar los males de la actualidad, bien merecen que en vez de rechazarlos con desdén, les prestemos benévola acogida, les estudiemos, y, después de conocerlos, procuremos unir nuestros esfuerzos a los de tan denodados campeones e imitar su glorioso ejemplo, llevando cada cual en su esfera humilde o elevada una piedra al edificio, que tan sólida y perfectamente cimentado nos presentan. Que sólo así, esclareciendo y aquilatando las cuestiones en el orden filosófico e irradiando luego clara luz sobre los espíritus, es como se facilitan las reformas en el estadio de la política, de la manera que todo hombre honrado, y que en su seno siente arder la pura llama de un acendrado patriotismo y del verdadero amor por sus semejantes, no puede menos de anhelar.

He terminado mi propósito, Excmo. Sr. A pesar de mi vehemente deseo de ser breve, lo vasto de la materia me ha impedido el realizarlo. Os pido de nuevo con encarecimiento vuestra indulgencia.

HE DICHO. 


\section{BIBLIOGRAFÍA}

CASTILlO CAMPOS, María Jesús del, Historia del balneario de Mondariz hasta 1936, Universidad Complutense de Madrid, Madrid 1993.

CORES TRASMONTE, Baldomero, Os senadores da Universidade de Santiago, Cuadernos de Estudios Gallegos, Anexo 26; Santiago de Compostela 1998.

FERNÁNDEZ CASANOVA, Carmen, La Sociedad Económica de Amigos del País de Santiago en el s. XIX: un estudio de la organización interna y de su actuación en favor de Galicia, Sada 1981.

FERNÁNDEZ CASANOVA, Carmen, "Real Sociedad Económica de Amigos del País de Santiago", Gran Enciclopedia Gallega 25, Santiago 1974, 102-104.

GARCÍA IGLESIAS, José Manuel, "Historia y arte en La Casa Grande del Pozo", Historia e Arte na Casa Grande do Pozo. Santiago de Compostela. Fundación Caixa Galicia, Santiago de Compostela 2002.

PARGA TORREIRO, Salvador (véase publicaciones).

PORTABALES VÁZQUEZ, Ángel, "Parga Torreiro, Salvador”, Gran Enciclopedia Gallega 24, Santiago $1974,40$.

\section{FUENTES}

Archivo General Militar de Segovia (AGMS), Expedientes personales, Ramón Parga Chans.

Archivo Histórico Universitario de Santiago de Compostela (AHUS), Universidad, Expedientes personales, legajo $1.008, \mathrm{n}^{\circ} .14$.

PARGA PONDAL, Isidro, Genealogía ascendente de Don Salvador Parga y Torreiro 1, Laxe 1980 [manuscrito inédito].

\section{PRENSA}

El Eco de Santiago, 29-4-1901; 6-5-1901.

La Gaceta de Galicia, 28-4-1901; 30-4-1901; 2-5-1901; 5-5-1901.

La Ilustración Española y Americana, 22-8-1884, 98-100.

\section{INTERNET}

Diario de las Sesiones de Cortes. Senado, 20-4-1892, 2757; 21-4-1892, 2761-71; 10-5-1892, 3090-5; 11-5-1892, 3101-8; 20-6-1892, 3722-5; 23-6-1892, 3823-8; 6-7-1894, 2633. Página de internet del Senado de España [http://www.senado.es]. 